\title{
チャ種子サポニンの植物生長阻害効果 \\ 一農薬との相乗効果についてー
}

\section{○木幡勝則・氏原ともみ・堀江秀樹 \\ （農林水産省野菜・茶業試酸場）}

演者らは、先にチャ種子サポニン（以下TSSと略称）が野菜類に対し生長調節作用のあ

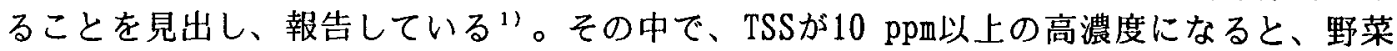
類の根の生長を阻害することに注目し、本研究では、化学農薬（除草郕）に代わるまた は軽娍できる天然物由来の植物生長阻害剈としてのTSSの利用の可能性について、化学農 薬と併用した場合の相乗効果の有無を中心に検討したので報告する。

\section{<実駼方法>}

植物生長阻害効果 : 雑草種子（ノビエ、(株)日本バイエルアグロケムより笴贈）30 35 粒をシャーレ中、十分にTSSおよび化学農薬を含む溶液で湿らせた 2 枚のろ紙上に置床 し、インキュベーター中 $25^{\circ} \mathrm{C} て ゙ 12$ 時間づつ明と暗を繰り返し処理して発芽させた。 4 日 後に発芽率と肧軸長および根長を測定した後、測定結果をボンフェロー二統計処理し、 コントロールとの比較からその阻害効果を判定した。TSSとして、1998年 9 月に野菜・茶 業試験場で採取した ‘やぶきた’ 種子より、演者らの既存の方法”に從い調製したサポ ニン混合物を用いた。また、化学農薬除草㓮としてグリホサート（関東化学製）を用い た。

\section{<結果と考察>}

（1）発芽率は、TSSおよびグリホサートともに濃度に関係なくほぼ100\%であった。

（2）図 1 と 2 には、ノビエ種子発芽（胚軸および根長）に及ぼすTSSの影響について、 同様に、図 3 と 4 にはグリホサートの影響について示した。前者では、肧軸に対して100 $\mathrm{ppm}$ 以上で、また、根長に対しては25 ppm以上で生育阻害効果のあることが明らかとな った。後者では、胚軸に対して $25 \mathrm{ppm}$ 以上で、また、根長に対しては $5 \mathrm{ppm}$ 以上で生育効 果のあることが明らかとなった。この結果より、グリホサートの方が約 5 倍程度効果の 強いことがわかった。

（3）図 5 と6には、グリホサート (2.5 ppm) に5〜50 ppmのTSSを加えたときの相乗 効果作用について示した。Cont.はグリホサート、TSSともに加えていないときの伸長で ある。胚軸に対しては、50 ppmのTSSを加えたときに阻害効果が認められ、この濃度はグ

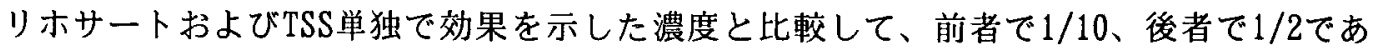
つた。一方、根長に対しては、25 ppmのTSSを加えたときに阻害効果が認められ、この濃 度はグリホサートおよびTSS単独での効果濃度と比較して、前者で1/2であったが、後者 では変化なかった。これらの結果から相乗効果のあることが、特に胚軸に対してその効 果の大きいことが明らかとなった。

（4）図 7 と 8 には、グリホサート（5.0 ppm）に5〜50 ppmのTSSを加えたときの相乗 効果作用について示した。肧軸に対しては、25 ppmのTSSを加えたときに阻害効果が認め られ、この濃度はグリホサートおよびTSS単独での効果濃度と比較して、前者で $1 / 5$ 、後 者で1/4であった。一方、根長に対しては、25 ppmのTSSを加えたときに阻害効果が認め られたが、この濃度はグリホサートおよびTSS単独での効果濃度と比較して、前者、後者 ともに変化がなかった。グリホサート（2.5 ppm）程でないまでも、グリホサート（5.0 $\mathrm{ppm}$ ) でも相乗効果のあることが明らかとなった。

1) 山内ら：農化講演要旨、P65、(1998) 


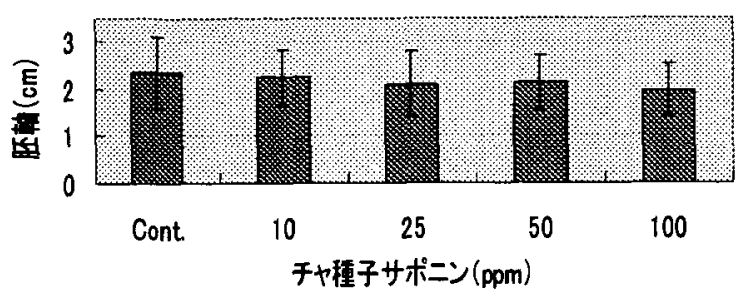

图1 ル゙エ種子発芽(肧軸)に及ぼすチャ種子サポニン の影響

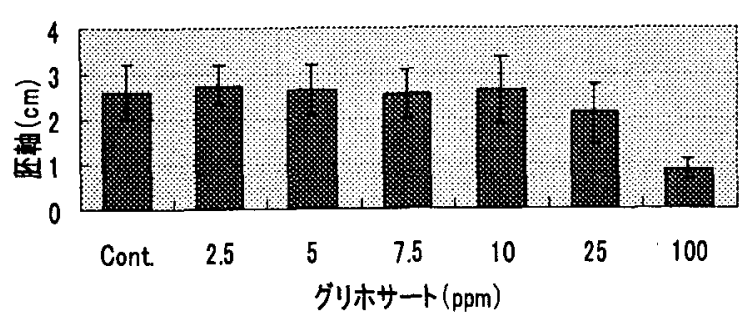

图3 ル゙エ種子発芽(肧軸)に及ぼすグリホサートの影 暨

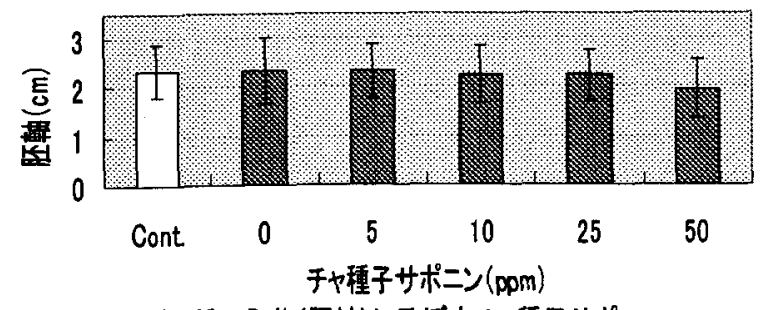

图5 ビエ理子発芽(肧軸)に及ぼすチャ種子サポニン とグリホサートの相乗效果作用

グリホサート2.5 ppm、Cont.はグリホサート0 ppm

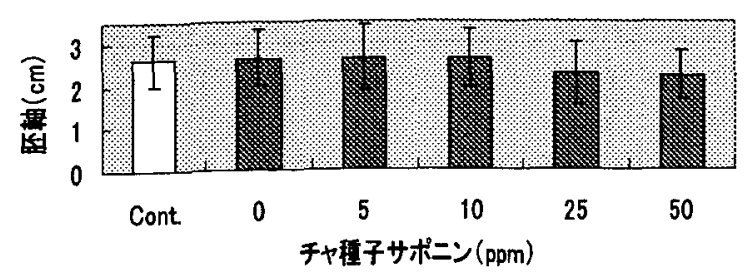

図7ル゙エ種子発芽(肧胴)に及ほすすチャ程子サポニン とグリホサートの相乗效果作用

グリホサート5.0ppm, Cont.はグリホサート0 ppm

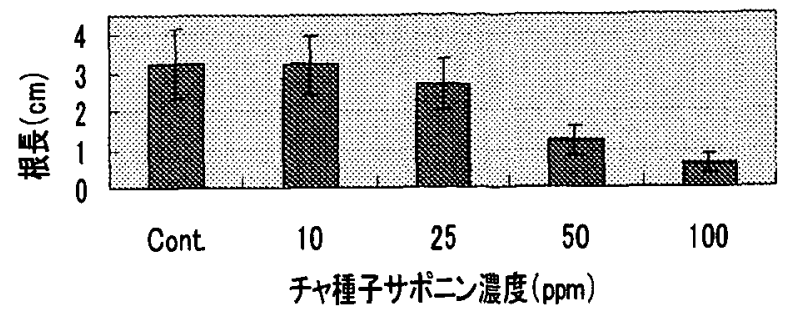

图2 ル゙エ種子発芽(根長)に及ぼすチャ種子サポニン の影響

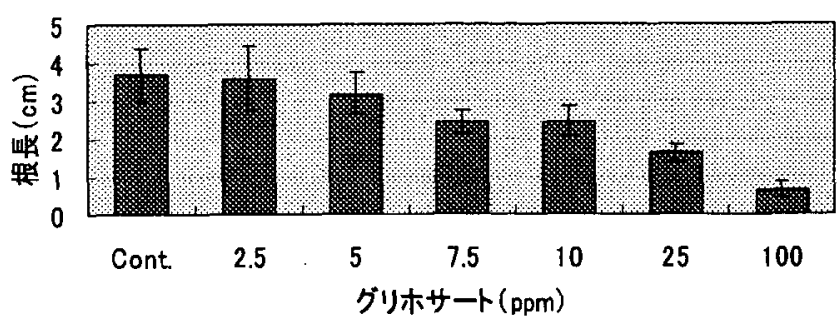

図4 ビエ種子発芽(根長)に及ぼすグリホサートの影琣

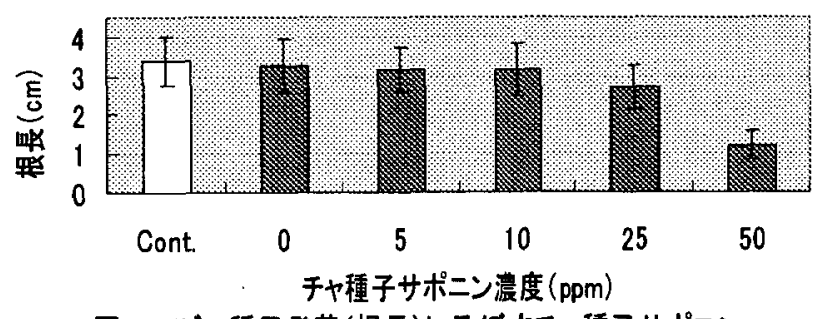

図6 ビエ種子発芽(根長)に及ぼすチャ種子サポニン とグリホサートの相乗勏果作用

グリホサート2.5 ppm.Cont.はグリホサート0 ppm

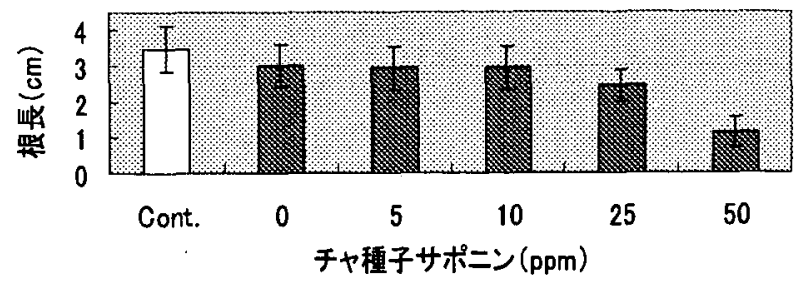

图8ノビエ種子発芽(根長)に及ぼすチャ種子サポ

ニンとグリホサートの相乗効果作用

グリホサート5.0ppm、Cont.はグリホサート0 ppm 


\section{木幡勝則・O原口隆文・过 正樹 ${ }^{1)}$ ・ 氏原ともみ・堀江秀樹

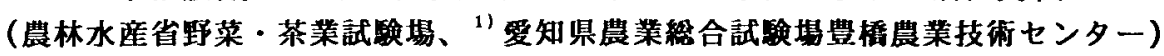

演者らは先に、蒸熱時間があまり变わらない市販玉露と比較して、市販抹茶中の残存 クロロフィラーゼ活性が低いのは、てん茶製造に特有の火炉による火入れ乾燥工程に起 因することを考察した ${ }^{1}$ 。また、フェオホルビドａ（PB a) がほとんど含まれていない のも、高温での乾燥工程においてクロロフィラーゼが作用できないためと考察した。今 回、これらのことを確かめることを目的に、てん茶製造工程における色素類含有量およ びクロロフィラーゼ活性の変化について検討し、興味ある知見を得たので報告する。

\section{<実験方法〉}

愛知県農業総合試験場豊橋農業技術センタ一で栽培され、2000年 5 月に機械摘みされ た‘やぶきた’を用いた。遮光期間は 30 日（前期：遮光率 $70 \%$ で 7 日間、後期 : 遮光率 $97 \%$ で23日間）。出開度 : $88.9 \%$ 、百芽重 : $118.3 \mathrm{~g}$ 。

製造条件：蒸熱時間；18秒、胴回転数； $40 \mathrm{rpm}$ 、擤挥軸回転数； $325 \mathrm{rpm}$ 、てん茶機； 7 間 5 段式、乾燥時間；一段目：1 分 40 秒、 $2 \sim 5$ 段目: 27 分。

サンプリングは生葉に標識を付け、蒸熱冷却、一段目乾燥、3 段目乾燥、および 5 段 目乾燥（てん茶荒茶）後にそれそれれ行い、これを 3 反復した。色素類含有量測定法およ びクロロフィラーゼ活性測定法に関しては、演者らの既存の方法に従った。

\section{<結果と考察〉}

（1）てん茶製造工程における各色素類の含有量変化を図 1 に示した。Chl $\left(a+a^{\prime}\right)$ およ びChl $\left(b+b^{\prime}\right)$ は製造工程とともに減少し、特に蒸熱冷却後と 5 段目乾燥後にその減少が大 きかった。Phy $\left(a+a^{\prime}\right)$ およびPhy $\left(b+b^{\prime}\right)$ は蒸熱冷却後に急增したが、その後Chlと同様に製 造工程とともに減少したことから、色素類の総含有量は工程とともに減少することが明 らかとなった。これらの変化を煎茶工程における変化（図 2 ) と比較すると、Chl $(b+b$ ')の減少がてん茶で大きかったことが、また、煎茶ではChl $\left(a+a^{\prime}\right)$ 拈よびChl $\left(b+b^{\prime}\right)$ が工 程とともに減少するが、Phy $\left(a+a^{\prime}\right)$ およびPhy $\left(b+b^{\prime}\right)$ が堿少とほぼ同じ割合で増加するこ とから、色素類の総含有量はほとんど変化したかったのに対し、てん茶では大きく減少 したことが大きな相違点であった。この原因として、てん茶の乾燥工程における各色素 類の分解が考えられ、この点がてん茶製造における特徽であることが明らかとなった。

（2）てん茶製造工程におけるChlのPhyへの变化率を図 3 に示した。変化率は一段目 乾燥までは增加するが、その後減少した。この傾向は、図4に示すように製造工程とと もに増加の一途をたどる煎茶の傾向と比較して大きな相違点であった。（1）で述べた ように、てん茶ではPhy $\left(a+a^{\prime}\right)$ およびPhy $\left(b+b^{\prime}\right)$ が製造工程とともに減少するが、このこ とが変化率を減少させた要因であり、この点もてん茶製造における特改といえる。

（3）てん茶製造工程におけるクロロフィラーゼ活性変化を四５に示した。酵素活性 は 5 段目乾燥後（荒茶）で生葉のそれの約 18 分の 1 であった。この值は、蒸熱時間50秒 で製造した煎茶（荒茶）のそれとほぼ同様の活性残存率であった。てん茶における剚熱 時間が 18秒と短かったことを考虑すれば、蒸熱後の煎茶の製造工程と比較して乾燥工程 での醭素失活が比較的大きかったことが明らかとなうた。

(4) PB aは全く含まれておらず、クロロフィラーゼが作用できなかったとしたこれ までの考察の正しかったことが裏付けられた。

Chl : クロロフィル、Phy : フェオフィチン、Chl(a+a'):Chl $a+$ Chl $a^{\prime}$

1)木幡ら：食科工、第 46 巻、725 730(1999). 


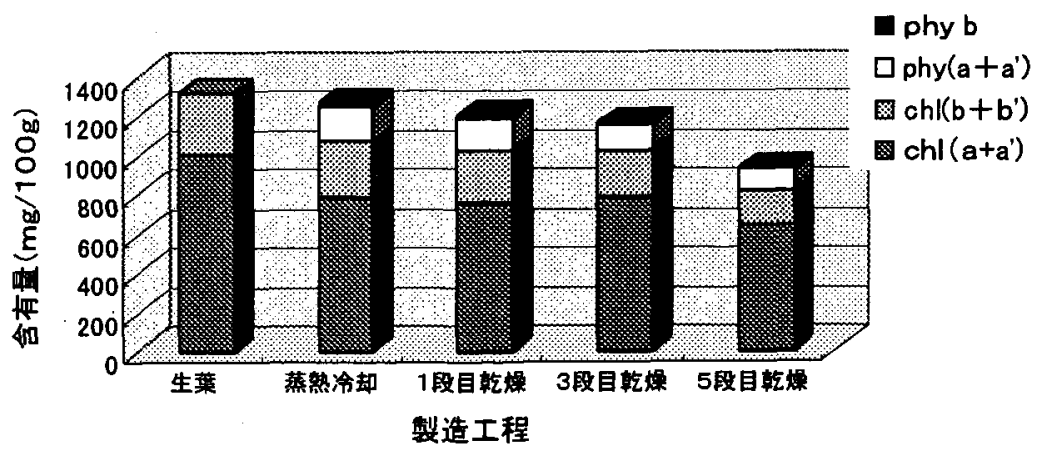

図1てん茶製造工程における各色素類の含有量変化

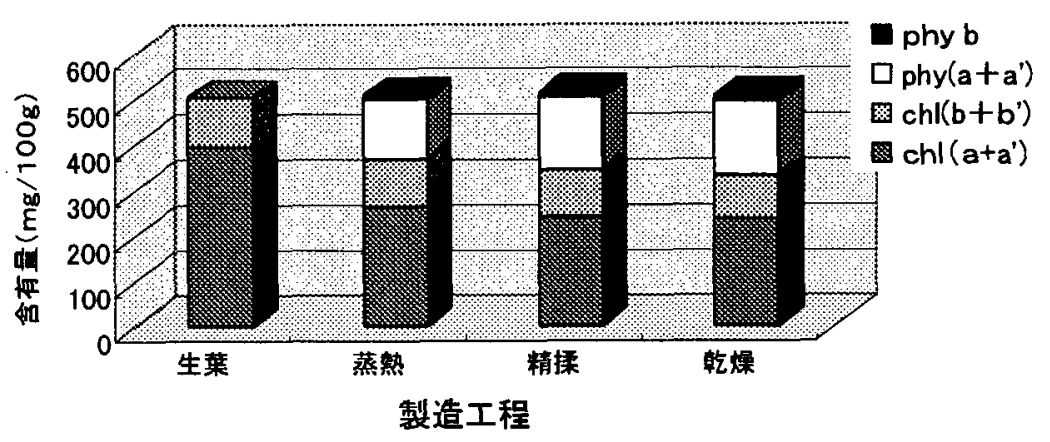

図2 煎茶製造工程における各色素類の含有量変化

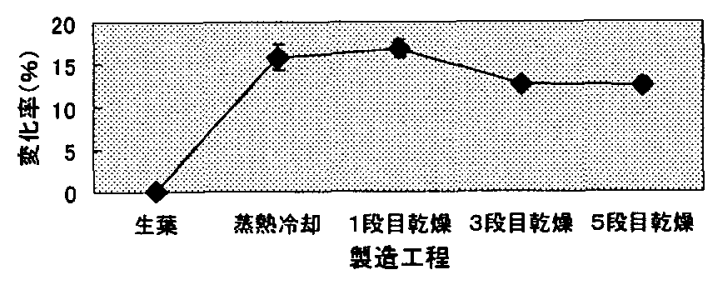

図3てん茶㡀造工程におけるクロロフィルの フェオフィチンへの变化率 $(\%)$

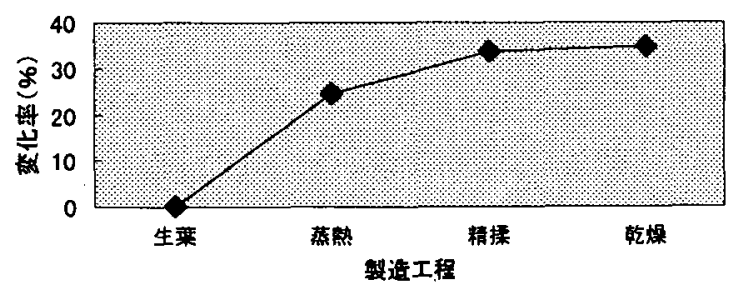

图4前茶製造エ程におけるクロロフィルのフェオフィチン への变化率 $(\%)$

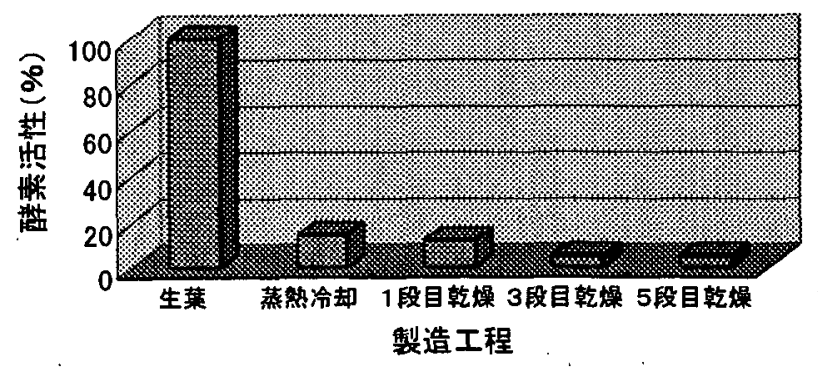

図5てん茶製造工程におけるクロロフィラーゼ活性変化 
有用生理活性の高いチャカルス培系の作出

青島洋一一竹元万寿美 ${ }^{1}$

(静岡県農業試験場、“静岡県立大学薬学部)

チャは高い内在性の醭活性を有し、この機能は今後医薬品製造工程など飲用 以外への利用が期待される。一方組織培斏技術は、人為的に制御可能な有用物質 生産の手段として注目され、特にカルス培養系は「(1)生理機能物澌の大量合成、 (2)生理譏能の効率的利用」等の面からメリットが大きい。今後チャの有用生理機能 の有効利用を図る上で、高い生理活性を有するカルス培養系の確立が重要である。

ここでは、カルスを詩導する組織及び誘導したカルスの培算条件について検討を 行った。

\section{【材料及び方法】}

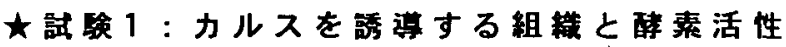

供試材料として、充実䡃子より摘出した子葉、一番茶新芽（2〜3葉開葉期）の 第一節間の部分を渝切り後絉断して調製した茎切片及び上から数えて2番目の葉から

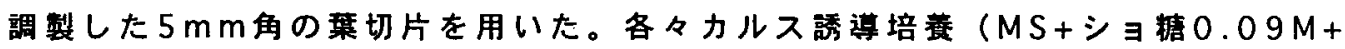
2,4-D：1〜3p pm、2 $7^{\circ} \mathrm{C}$ 暗黒条件下、45〜62日) を行い、誘覃したカルスのペル オキシダーゼ活性を「○ーアミノフェノール法」により測定した。

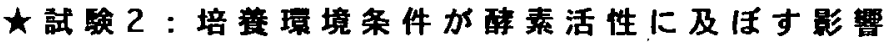

供試材料として'さやまかおり’子葉から誘導したカルスを継代培養して用いた。

「植物ホルモン」としてMS+ショ糖0.09Mを基本にABA $(0 \sim 40 p p m)$ 又は2,4-D $(0 \sim 10 \mathrm{ppm})$ を含む固形培地にて、また「浸透ストレス」としてMSを基本にショ糖 $(0 \sim 0.4 \mathrm{M})$ 及びマンニトール $(0 \sim 0.4 \mathrm{M})$ を含む培地にて、各々 $27^{\circ} \mathrm{C}$ 暗黒条件 下61日間培䃆を行った。そして增殖したカルスのペルオキシターゼ活性を湘定する とともに形成したカルスの大きさを0〜5のグレードで表し、カルス当たりに平均した 数值を「カルスグレード值」として評価した。

\section{【跿果及ひ考察】}

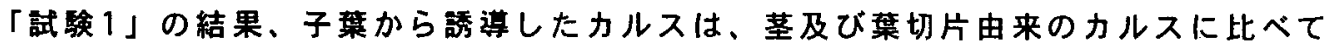
カルス $1 \mathrm{~g}$ 当たりの醇素活性が高くなる傾向にあった（図1）。

また、「試験 2」の結果、培地に添加するホルモンでは、2,4-Dを添加することに より醇素活性か $2 〜 3$ 倍高まった（図 2）。浸透ストレスでは、ショ糖+マンニトール が0.3M以上でショ搪濃度が0.2M以上の時に対照（ショ糖0.09M）より醉素活性が高

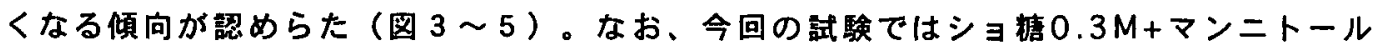

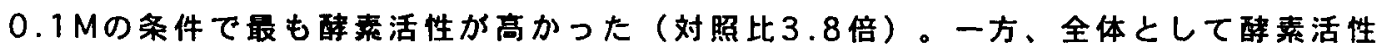
が高い時にカルスグレード值が低くなる傾向にあった。

以上の結果、ペルオキシダーゼ活性の高いカルス培条件として、今回の試験では 「(1)カルスを誘導する材料として実生（子葉）を用いること、(2)カルス培費培地への 2,4-Dの添加、(3)カルス培善中の漫透ストレス処理」が効果的であると考えられた。 

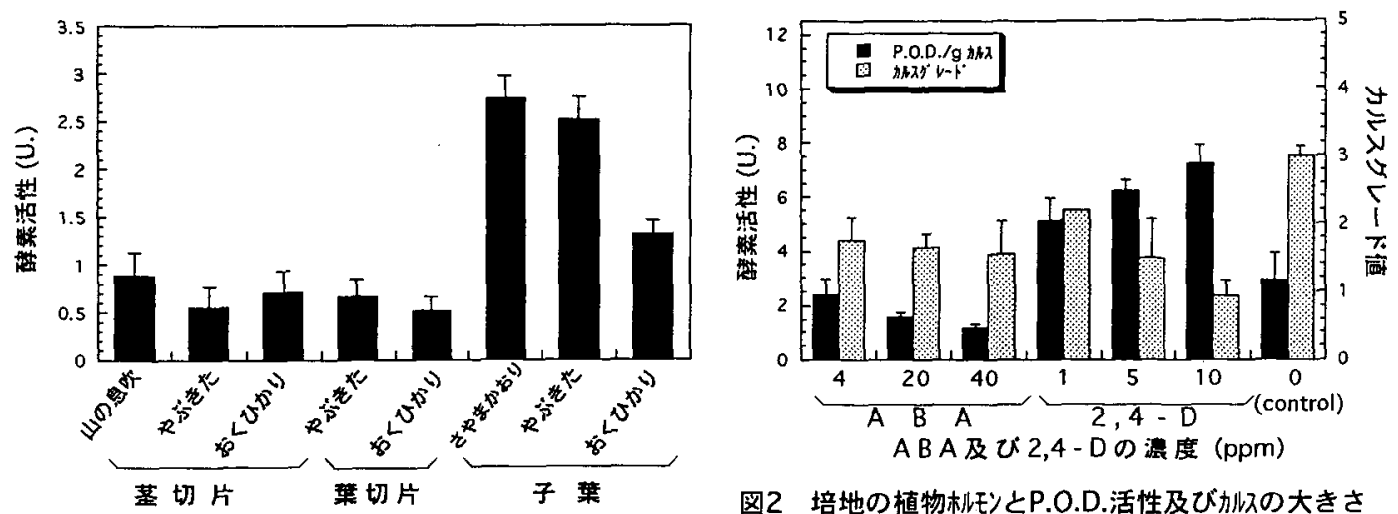

図2 培地の植物机ンとP.O.D.活性及び九ルスの大きさ

图1 各組織から謤通したカルスのP.O.D.活性

※ エラーバーは標準偏善 (S.D.) を表す

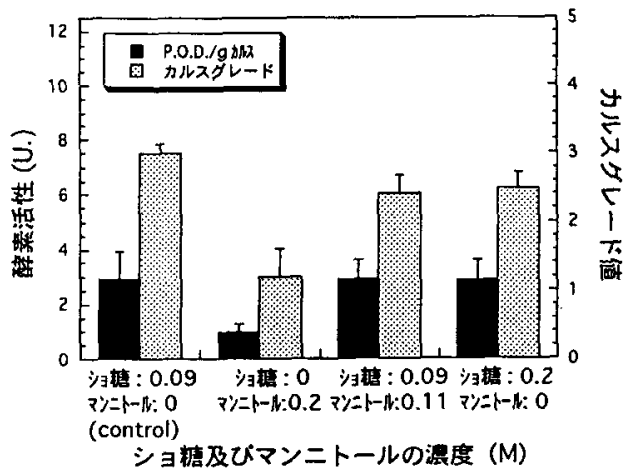

図3 培地の漫透不怆とP.O.D.活性及びかhスの大きさ

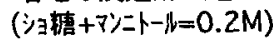

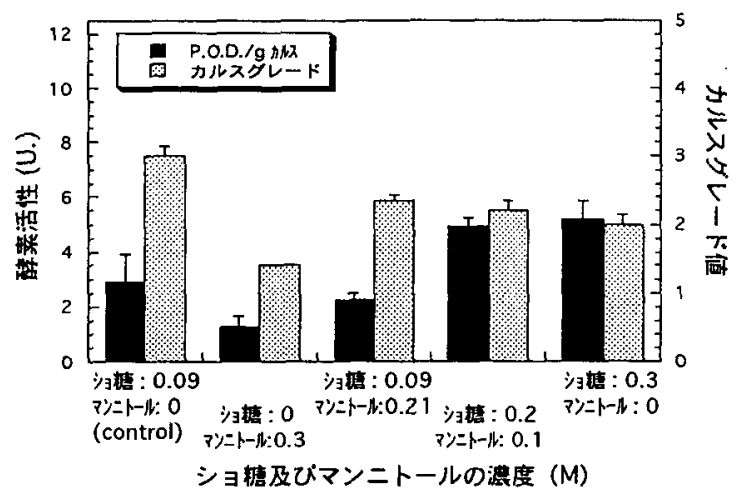

図4 培地の浸透不㤆とP.O.D.活性及び加スの大きさ (シ3糖+マンニトート $=0.3 \mathrm{M})$

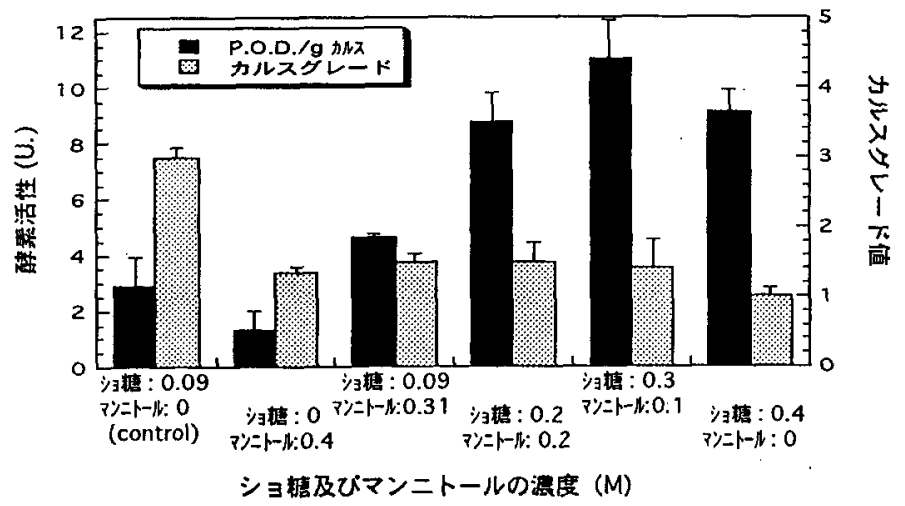

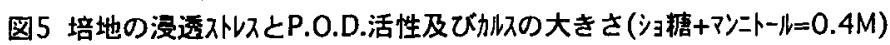

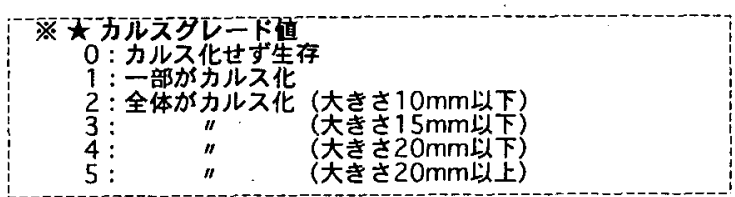




\section{茶に含まれるシュウ酸について \\ （第 2 報）全シュウ酸及び水溶性シュウ酸含量の変動 \\ ○堀江秀樹・氏原ともみ・木幡勝則 \\ （農水省野菜・茶業試験場）}

水溶性シュウ酸は各種茶に $1 \%$ 前後含まれ，茶樹を遮光することによってその 含量が增加することを報告した”。また，シュウ酸が茶の舌に残る“あと味”に 寄与するとの推测を行っている2!。ところが茶葉を食する機会が增加した今日に おいては，浸出液に溶け出す水溶性シュウ酸だでなく，塩酸で抽出される全シ ユウ酸の含量に関する知見も必要であると考えられる。そこで，本講演において は，キャピラリー電気泳動法を用いた全シュウ酸の定量法を開発し，この方法を 用いて, 摘採時期, 窒素肥料, 摘採部位とシュウ酸含量（全シュウ酸及び水溶性 シュウ酸)の関係についての解析を試みた。

\section{実験方法}

粉砕試料を $0.2 \mathrm{M}$ 塭酸により抽出し， $1 \mathrm{M}$ 水酸化ナトリウムで中和したものを 全シュウ酸分析用試料，粉砕試料を熱水抽出したものを水溶性シュウ酸分析用試 料とし，これらの試料を既報 ${ }^{3} に$ 従いキャピラリ一電気泳動法により分析した。 供試した材料は，すべて野菜・茶業試験場（静岡県榛原郡金谷町）の試験固場に おいて栽培したものである。

\section{実験結果と考察}

キャピラリー電気泳動法を用いて全シュウ酸分析を行うためには，塩酸に由来 する塭化物イオンとシュウ酸イオンの泳動時間が近接するため，分析条件に留意 する必要がある。既に報告している有機酸分析法により，これらのイオンに由来 するピークは分離できることが確認された。ただし，分析試料が酸性を示す場合 にはシュウ酸イオンのピークが小さくなる傾向があり，抽出試料の中和操作は必 須である。茶の塩酸抽出液を分析した結果を図 1 に示した。

一番茶期及び二番茶期に枠摘みした“めいりょく’の芽について, 全シュウ酸 及び水溶性シュウ酸の分析を行った結果を図 2 に示した。各茶期とも，摘採が遅 れるほど全シュウ酸については含量が低下する傾向が認められたが, 水溶性シュ ウ酸については明瞭な変化は認められなかった。”また水溶性シュウ酸については, 一番茶期よりも二番茶期において高い傾向功認められた。この傾向は‘おくゆた か’においても同様であった。

窒素施肥量を変えて栽培した畨場から機械摘採した‘やぶきた’一番茶芽につ いて,シュウ酸含量を比較したところ, 窒素施肥量の少ない区において全シュウ 酸及び水溶性シュウ酸の含量が低い傾向がみられた（図 3 )。

二番茶芽の部位によるシュウ酸含量の差異について図 4 に示した。下位の茎葉 は上位の荎葉に比べて水溶性シュウ酸の含量や割合が低かった。

\footnotetext{
1) 茶研赧，No.87別，118-119（1998） 2) 茶研報, No.89, 23-27 (2000) 3 3) J. Chromatogr. A, 817 139-144 (1998)
} 


\section{全シュウ酸分析のための䀦料調数}

1. 粉末化した試料 $100 \mathrm{mg} 10 \mathrm{~m} /$ 容 の共栓つき試験管に秤量する。

2. $0.2 \mathrm{M}$ 塩酸 $10 \mathrm{~m} 1$ を加え摚拌後， 室温で 1 時間放置する。

3. $100 \mathrm{~m}$ 容のメスフラスコに洗いこみ， 1 M水酸化ナトリウムで中和し，

0. $25 \mathrm{mM}$ になるようEDTAのナトリゥム塩 を添加しメスアップする。

4. $0.45 \mu m$ のメンブレンフィルターを 通し，キャピラリー電気泳動による 分析の試料とする。

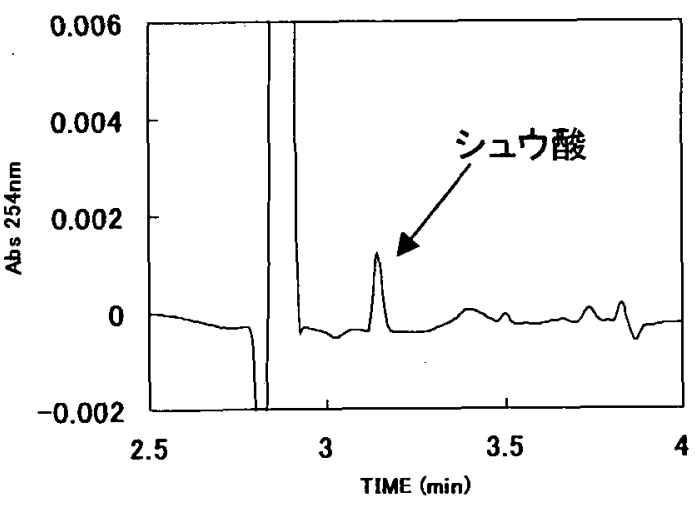

図1 茶葉の塩酸抽出液のフェログラム 塩酸濃度 $0.2 \mathrm{M}$

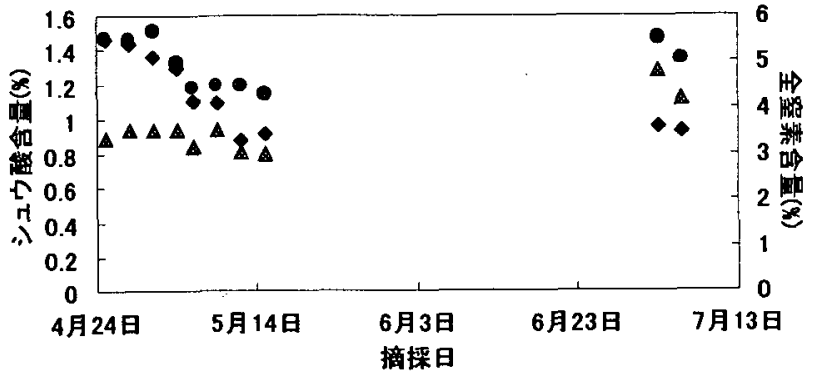

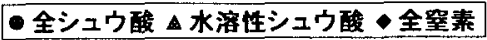

図2 'めいりょく’の全シュウ酸, 水溶性シュウ酸 及び全窒素含量の変動

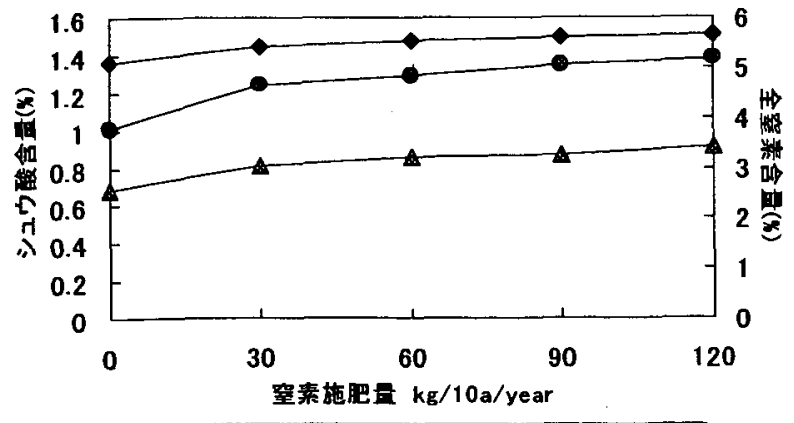

全シュウ酸 ーA 水溶性シュウ酸一全哣素

图3 窒素施肥量と摘操芽中のシュウ酸及び全窒素の含畐の関係 1999年“やぶきた’一番茶
上位

中位

下位

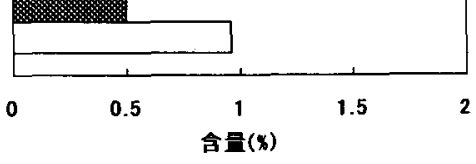

口全シュウ酸 因水溶性シュウ酸

図4摘採芽の部位とシュウ酸含量の関係 7月3日に操取した“おくゆたがの二番茶芽。 心から第3葉までを上位，4葉までを中位， それ以下を下位とした。 


\section{品種「さきみどり」の粉末状態における}

葉色評価と食品素材への利用

○高嶋和彦・黒木高幸・平川良子 ${ }^{11}$ - 堀江秀樹 ${ }^{2)}$ - 木幡勝則 ${ }^{2}$

(宮崎県総合農業試験場茶業支場、“宮崎県食品開発センター、 ${ }^{2}$ 農林水産省野菜・茶業試験場)

品種「さきみどり」のクロロフィル（ChI）について、前回、その含有量が「や ぶきた」に比べて多いことを報告したが、今回、粉末状態での葉色評価と食品素 材としての利用の可能性について検討した。

\section{<実験方法>}

2000年度に肥培管理が同じ一番茶の「さきみどり」と「やぶきた」について、 露地、被覆（摘採前 5 日間、遮光率 $90 \%$ の被覆資材で遮光）の原料を摘採適期に はさみ摘みし、 $2 \mathrm{~K}$ 型製茶機を用いて製造（45秒蒸し・中揉出し乾燥）した。火 入れ後、石臼を用いて粉末化した茶とこれを用いて試作したアイスクリームの色 について、目視と測色計（ミノルタ分光測色計 CM-508d）により評価した。対照 として市販の料理用抹茶 2 種類（上：1, 000円 $/ 40 \mathrm{~g}$ 、並：600円 $/ 40 \mathrm{~g}$ ）を用い た。また、上述した供試茶及び表 1 の条件で製造した荒茶について、Chlとフェオ フィチン (Phy) 含有量をHPLC法を用い測定した。

〈結果及び考察〉

1. 粉末茶の目視による葉色評価の結果、抹茶(上)、「さきみどり」被覆の順に 評価が高く、「やぶきた」露地が最も低かった。両品種の露地、被覆間の比較で は「さきみどり」の評価が有意に高く、「さきみどり」被覆は緑が鮮やかで、

「やぶきた」露地は白っぽく見えた（表 1)。

測色計で計測した結果、「さきみどり」露地、被覆とも「やぶきた」に比べて、 一 a *値（緑色方向の色相）が高く、特に「さきみどり」被覆は抹茶(並)よりも一 a *值、C*値（あざやかさ）とも高かった。「やぶきた」露地はし*值（明度）が 高く、ー a *值が最も低い值を示した（図1）。

2.アイスの目視による色彩評価の結果、抹茶(上)、「さきみどり」被覆の順に 評価が高く、「やぶきた」露地が最も低かった。両品種の露地間、被覆間では

「さきみどり」が「やぶきた」よりも有意に評価が高く、「さきみどり」被覆は 抹茶(並)に比べ有意に評価が高かった（表 1 ）。

3.アイスクリーム供試茶のChl含有量は、「さきみどり」が「やぶきた」に比へ て多く、特に「さきみどり」被覆は抹茶（上）と同程度の含有量であった（図 2 ）。

以上の結果から、粉末状態とアイスクリームの色の評価はほほ類似しており、 またChI含有量とも相関性が高い。両品種の露地、被覆間の比較では「さきみど り」が明らかに評価が高く、特に「さきみどり」被覆は料理用抹茶と比較しても 食品素材として実用的に利用できる程度の葉色品質を持つと考えられた。また、 二番茶についても、表 2 の結果から「さきみどり」は、Chl含有量が「やぶきた」 に比べて多く、葉色及び食品素材としての有用性は高いと推測された。 
表 1 粉末茶、アイスの目視による葉色、色彩評価

\begin{tabular}{|c|c|c|c|c|}
\hline \multirow[b]{2}{*}{ サンプル名 } & \multirow{2}{*}{$\begin{array}{c}\text { 粉末茶 } \\
\mathrm{n}=15\end{array}$} & \multirow{2}{*}{$\begin{array}{l}\text { アイス } \\
n=33\end{array}$} & \multicolumn{2}{|l|}{ 四 } \\
\hline & & & 評点 & 内容 \\
\hline 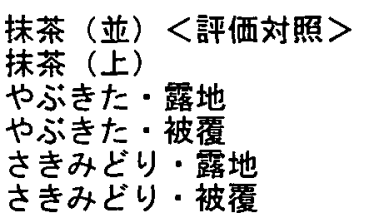 & $\begin{aligned} 0.0 \mathrm{bc} \\
2.2 \mathrm{~d} \\
-2.4 \mathrm{a} \\
-0.4 \mathrm{~b} \\
-1.1 \mathrm{~b} \\
1.0 \mathrm{c}\end{aligned}$ & $\begin{aligned} 0.0 \mathrm{~b} \\
2.1 \mathrm{~d} \\
-1.7 \mathrm{a} \\
-0.4 \mathrm{~b} \\
-0.1 \mathrm{~b} \\
0.8 \mathrm{c}\end{aligned}$ & $\begin{array}{r}2 \\
1 \\
0 \\
-1 \\
-2 \\
-3\end{array}$ & $\begin{array}{l}\text { や良い } \\
\text { 同程度 } \\
\text { やや悪い } \\
\text { 悪い } \\
\text { 大変悪い }\end{array}$ \\
\hline
\end{tabular}

評価は粉末茶、アイス別々に行い、数値は抹茶（並）を基準として右の評価点をもとに個別評価の平均 点であり、 $\mathrm{n}$ は評価人数を示す。平均値の差をサンプル間でテューキーの多重比較により検定し、平均値 の横のアルファベットが同一であれば、5\%水準で有意差がないことを示す。
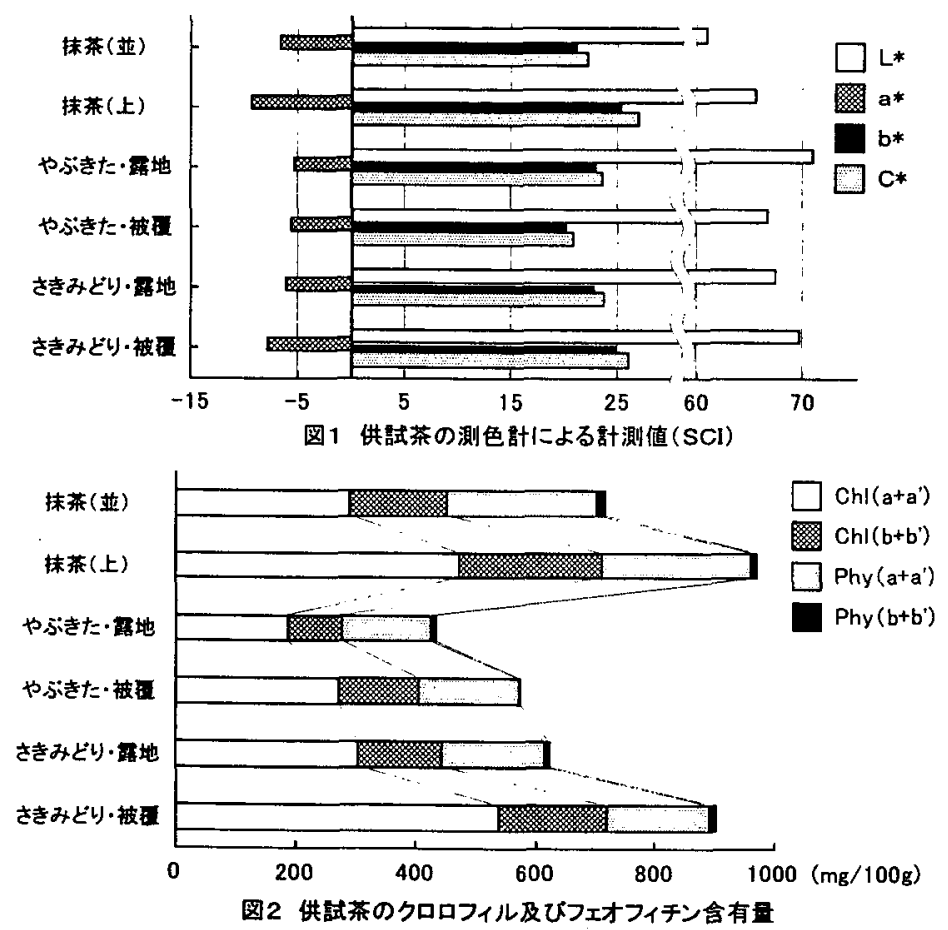

表 2 一心三葉摘みで製造した荒茶のCh1及ひPPhy含有量

\begin{tabular}{|c|c|c|c|c|c|c|}
\hline 原料 & & $\operatorname{Chl}\left(a+a^{\prime}\right)$ & $\operatorname{Chl}\left(b+b^{\prime}\right)$ & $\operatorname{Phy}\left(a+a^{\prime}\right)$ & $\operatorname{Phy}\left(b+b^{\prime}\right)$ & Phyへの変化率 \\
\hline 一番茶・やぶきた & $\begin{array}{l}\text { 露地 } \\
\text { 被嗄 }\end{array}$ & $\begin{array}{l}210 \\
321\end{array}$ & $\begin{array}{r}64 \\
108\end{array}$ & $\begin{array}{l}111 \\
142\end{array}$ & $\begin{array}{l}8 \\
8\end{array}$ & $\begin{array}{l}31 \\
26\end{array}$ \\
\hline 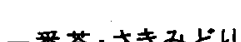 & 露地 & 459 & 114 & 124 & 8 & 19 \\
\hline • 己 & 被覆 & 533 & 163 & 140 & 6 & 18 \\
\hline 一来荓，也ラ゙きた & 露地 & 198 & 100 & 193 & 13 & 42 \\
\hline 番种・やふさた & 被表 & 266 & 124 & 194 & 13 & 35 \\
\hline 一番荅・さきみよ゙け & 露地 & 278 & 107 & 192 & 12 & 35 \\
\hline 番条・ささみとり & 被是 & 353 & 148 & 215 & 12 & 31 \\
\hline
\end{tabular}

摘採適期に一心三葉の手摘みの原料を50 g 型微量製茶機を用いて簡易憋造した荒茶を分析した。被覆期 間は一番茶が摘採前 5 日間、二番茶が 3 日間被覆資材（遮光率 $90 \%$ ）で遮光した。 
茶葉搾汁液粉末の機能性評価

○木村泰子・原口健司

(京都府立茶業研究所)

当所が開発した茶葉㩁汁液粉末は、従来の製茶工程と異なる製造法のため、 一般の茶とは成分の組成が異なり、それに伴い、機能性も異なってくることが 考えられる。そこで茶葉㩁汁液粉末の機能性を比較検討した。

1. 方法

【控汁液粉末の調整方法】茶葉㩁汁液粉末は、図 1 の方法により調整した。原 料は二番茶芽を用い、平成 12 年 6 月 28 日製造分(以下粉末 628 ) 露天の ‘京 研 129 号”、6月 29 日製造分(以下粉末 629)は一重被覆(期間 10 日)の“やぶき た’を用いた。比較としての煎茶、川柳は当所の平成 12 年度産(一番茶)を使 用した。また、化学成分分析については常法によった。

【DPPHによるラジカル消去能】内山ら ${ }^{1)}$ の方法により測定した。

【 $\beta$ 一カロチン退色法による抗酸化能】津志田ら ${ }^{2)}$ の方法により測定した。

【メチルメルカプタンに対する消臭作用】宇井ら ${ }^{3)}$ の方法により测定した。

【黄色ブドウ球菌に対する抗菌性】Staphylococcus aureus IFO12732を供試 菌として、各濃度試料添加の Nutrient Agarにおける $37^{\circ} \mathrm{C} 24$ 時間培養後のコ ロニー形成の有無を調査した。

\section{2. 䊅果及び考察}

1 ）粉末 628、629 は、ともに原料蒸葉、煎茶、川柳と比べてタンニン、遊離 アミノ酸、アスコルビン酸、カフェインの含量は多かった(表 1)。

2 ）粉末 628、629 はともに煎茶、川柳よりもラジカル消去能、抗酸化能は高 かった（図 2、3）。これは、搾汁液粉末のタンニン、アスコルビン酸含量が多か ったためと考えられた。

3) 試料重量 $2 \mathrm{mg}$ のときのメチルメルカプタン $2 \mu \mathrm{g}$ に対する消臭率は、図 4 に示すようにいずれの試料についても $30 \%$ 前後であり、今回分析した成分との 関連は見いだせなかった。

4) 粉末 628、629 はともに煎茶、川柳より低い濃度で抗菌活性を示した(表 2)。これは、㩁汁液粉末のカテキン含量が多く、またその組成の違いによるも のと考えられた(表 3)。

以上のことから茶葉搾汁液粉末は従来の茶と同等もしくは高い機能性をも つと評価でき、その理由として機能性成分であるカテキン、アスコルビン酸を 多く含むためと思われた。

1)内山ら: 薬学雑誌、88,678(1968)

2) 津志田ら：食工誌、Vol.41; No.9,611-618(1984)

3) 宇井ら：食工誌、Vol.38,No.12,1098-1102(1991) 


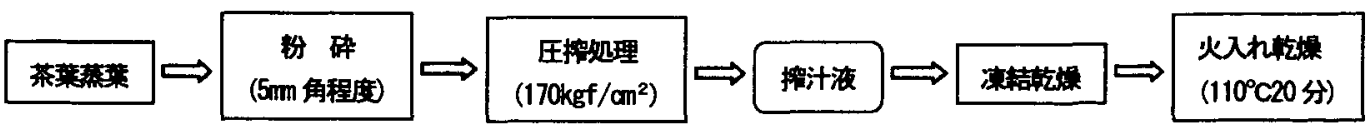

図 1 茶葉搾汁液粉末の製造法

表 1 茶葉挖汁液粉末の化学成分值 (\%)

\begin{tabular}{|c|c|c|c|c|c|c|}
\hline & & 乌人ニン & 全窒素 & 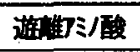 & 加I保 & 7スב代 酸 \\
\hline \multirow[t]{2}{*}{ 粉末 628} & 原料蒸葉 & 14.9 & 4.22 & 1.36 & 2.57 & 0.49 \\
\hline & 铂末 & 24.9 & 2.67 & 4.71 & 4. 69 & 2. 25 \\
\hline \multirow[t]{2}{*}{ 妢末 629} & 原料䙵葉 & 13.4 & 4. 21 & 1.57 & 2. 84 & 0.35 \\
\hline & 汾末 & 21.7 & 2. 66 & 5.34 & 4. 85 & 1. 68 \\
\hline 然茶 & & 15.1 & 5.55 & 3. 10 & 3. 35 & 0.46 \\
\hline 川㨨 & & 13.8 & 4. 87 & 2.92 & 2.75 & 0.41 \\
\hline
\end{tabular}

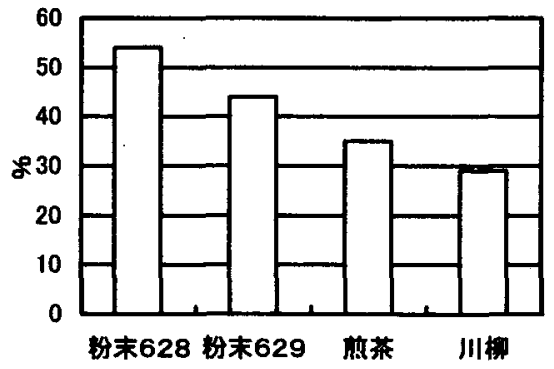

図 2 試料源度 100ppm のときのラジカル消去能 （水の消去能を $0 \%$ とする比較）

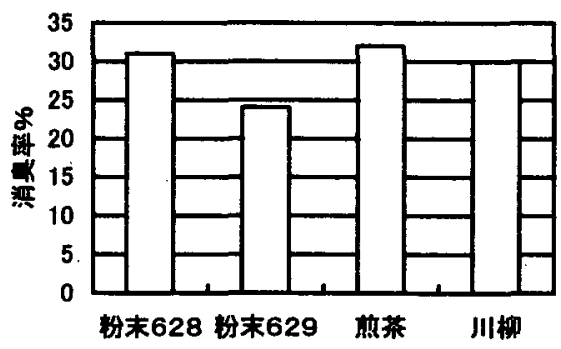

図4メチルメルカプタンに対する消臭効果 (水の消系率を0\%とする比較)

表2 Staphylococcus aureusに対する抗菌性

\begin{tabular}{|c|c|c|c|c|c|}
\hline & 1600 & 1200 & 800 & 600 & 400 (ppmi) \\
\hline 行末 628 & & & - & - & + \\
\hline 行末 629 & & & - & + & + \\
\hline 斯来 & - & + & + & & \\
\hline 川柳 & - & + & + & & \\
\hline
\end{tabular}

コロニーの形成 有 : + 無 : -

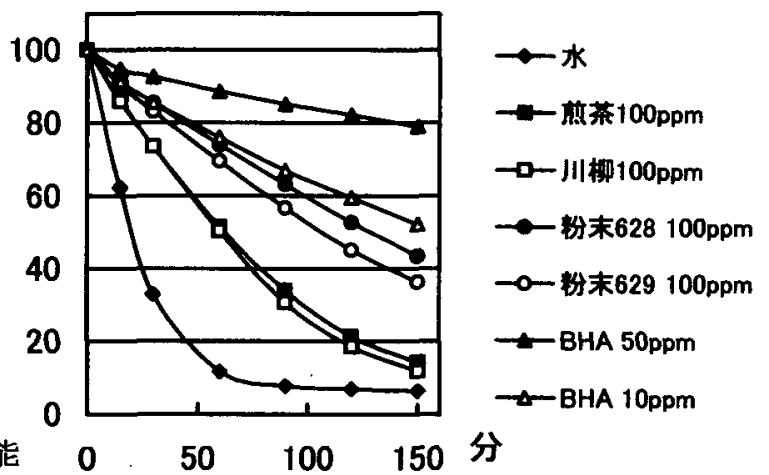

図3 抗酸化能の比較

（0分のときの吸光度を 100 とする）
表 3 試料のカテキン組成（\%)

\begin{tabular}{|c|c|c|c|c|c|c|}
\hline & $E G C$ & $(+) C$ & $E C$ & ECCG & $E C G$ & 加倣针 \\
\hline 妢末 628 & 14.59 & 0.50 & 2. 30 & 5. 93 & 1.39 & 24. 71 \\
\hline 妢末 629 & 11.87 & 0.42 & 1.87 & 5.03 & 0.99 & 20. 18 \\
\hline 音茶 & 4. 76 & 0.25 & 1.01 & 7.43 & 1.79 & 15. 24 \\
\hline 川卿 & 4. 94 & 0.21 & 1.01 & 6.22 & 1.38 & 13.76 \\
\hline
\end{tabular}




\section{超音波透過法による茶葉の物理的特性計測}

○福原幹夫 ${ }^{1)}$. 出川智久 ${ }^{1)}$. 奥島里美 ${ }^{21}$ ・松尾喜義 ${ }^{31}$ ・本間知夫 ${ }^{4}$

(1)東芝タンガロイ株式会社、2)農業工学研究所、

3)野菜・茶業試験場、4)東京医科歯科大学)

演者らはこれまで超音波を利用して、金属やボリマ一等の粘弾性特性評価に関 する研究を行ってきた 'が、最近この技術を作物の葉の物理的特性計測へ応用す る試みを開始している ${ }^{2)}$ 。葉を収㮃する作物の中でも茶葉は生の葉を製茶して荒 茶に加エすることによって製品となるため、生葉の状態を適切に評価して最適の 加工を施す必要があり、葉の状態を迅速・簡便・定量的に評価できる手法の開発 が望まれてきた。そこで本研究では、超音波透過法を茶葉に適用し、茶葉の持つ 物理的特性と超音波透過特性との関係について検討した結果を報告する。

\section{【材料および方法】}

調查した茶葉は野菜・茶業試験場（金谷）の“やぶきた’で、一番茶を摘採せ ずそのまま伸ばした状態の枝から、種々の成熟程度の葉を6月下旬に越冬葉も 含め 140 枚採取した。超音波透過法の概要は図 1 に示した。水中に送信側振動 子・受信側振動子（いずれも直径 $4 \mathrm{~m} \mathrm{~m}$ ) を一定の間隔 $(10 \mathrm{~mm})$ で固定し、そ の中間に茶葉を垂直に固定し、周波数 $3.3 \mathrm{MHz}$ の縱波超音波を発振させた。超 音波の送受信执よび波形解析には音診機（東芝タンガロイ、音診機 USH-H）を 用いた。また超音波測定を行った茶葉の各部位について厚さ、剪断力、含水率を 測定した。なお各測定部位は図 2 に示す 5 力所で行い、葉が小さい場合は(1)(2) のみとした。

\section{【結果および考察】}

1 回の測定に必要な時間は 1 分以内であった。茶葉を透過した超音波の波形解 析から、透過波の中心周波数は $1.2 \sim 1.7 \mathrm{MHz}$ 、位相は $0.3 \sim 2.1 \mathrm{rad}$ 、位相速度 は $250 \sim 1100 \mathrm{~m} / \mathrm{s}$ 、対数減衰率は $0.1 \sim 1.4$ であった。また測定部位における厚 さ、剪断力、含水率はそれぞれ $0.1 \sim 1.3 \mathrm{~m} \mathrm{~m} 、 100 \sim 2000 \mathrm{gf}$ （直径 $5 \mathrm{~m} \mathrm{~m}$ ）、0.57 〜0.87 の範囲に分布していた。これらのパラメータ間の相関を調べたところ、 新芽や上位葉の柔らかい部分で高い中心周波数を示し、下位葉になるほど周波数 が低くなる傾向が見られた。また葉の厚さ（図 3 および 4）と剪断力（図 5) で は音響パラメータと密接に関係することが明らかとなった。今回は茶葉の物理的 特性として厚さ、剪断力、含水率の 3 要素のみを調べたに過ぎないか、茶葉の 物理的特性が超音波透過波の情報を利用して簡便、非破壊的に計測できる可能性 が明らかになった。

【参考文献】

1) Fukuhara et al., J.Polmer Sci.: Polm.Phys,, 37, 497-503 (1999)

2) 福原他、第 20 回超音波シンポジゥム講演予稿集、237-238 (1999) 


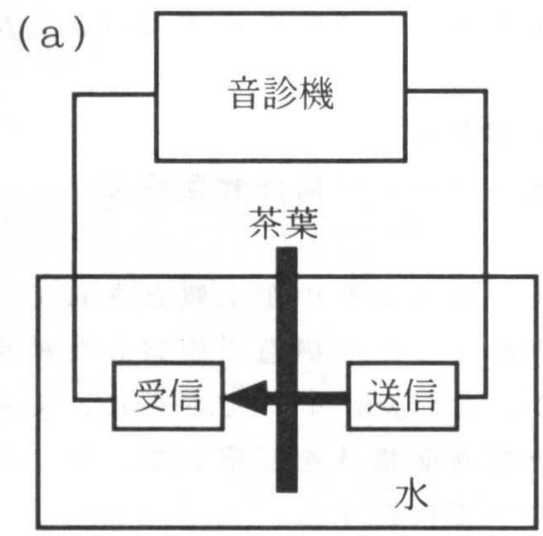

図 1 测定方法

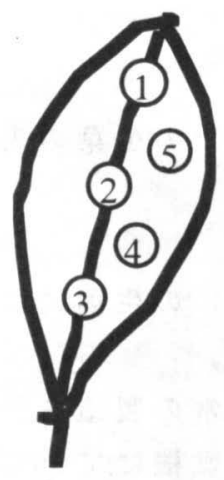

図 2 測定部位 (b)

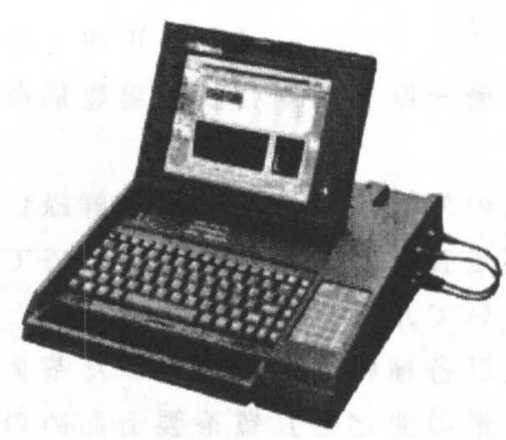

(b) 音診機

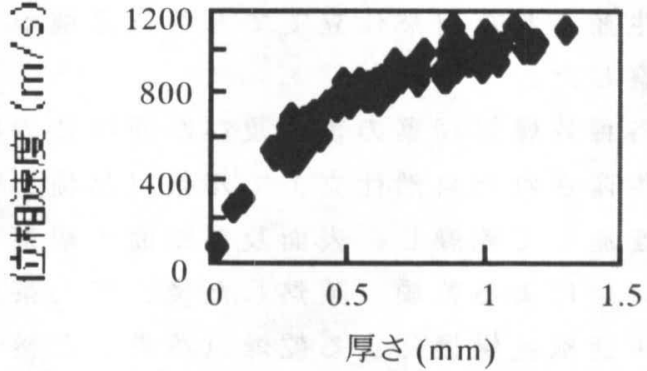

図3茶葉の厚さと位相速度の関係

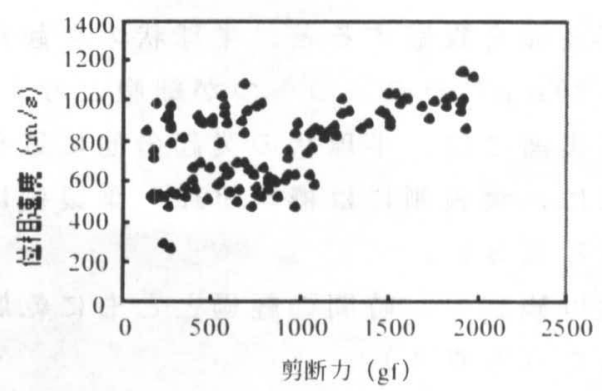

図 5 茶葉の剪断力と位相速度の関係 
走查型電子顥微鏡によるてん茶生葉と各種乾燥処理葉の表面及び 断面構造の観察

○过 正樹 - 木下忠孝 · 加藤保 ${ }^{11}$

（要知県農業総合試験場豊橋農業技術センター、”同経営想境部）

てん茶の外観品質は一般的に鮮緑色で「さえ」のあるものが上質とされている。 筆者らが走查型電子影微鏡を用いててん茶の表面及び断面構造を観察した結果、 厚さの薄いてん茶ほど品質が高いことが明らかになった。そこでさらに、てん茶 の生葉及び各種乾燥処理を施した茶葉の表面及び断面構造を観察して、加工に伴 う茶葉構造の変化と良質茶製造ための要因について検討する。

\section{【材料及び方法】}

走查型電子顕微鏡は、株式会社ニコン製のESEM-20を用いた。パソコンへの画像 の取り込みは付属のソフトウェア「IAAS (Image Acquisition and Archiving System) Ver. 1.01: ElectroScan 社」によって行った。

試験 1 てん茶生葉の表面及び断面構造の観察

所内で生産された自然仕立ててん茶（品種：やぶきた）の生葉の表面及び断面 構造を観察した。

試験 2 各種乾燥処理葉の表面及び断面構造の観察

所内で生産された自然仕立ててん茶（品種：やぶきた）の生葉について以下の 各種処理を施して乾燥し、表面及び断面の観察を行った。

(1)てん茶炉による乾燥（蒸熱した後、てん茶炉にて通常の製造を行った。）

(2)蒸熱 + 通風乾燥機による乾燥（蒸熱した後、通風乾燥機にて $80^{\circ} \mathrm{C}$ 、一昼夜乾 嬠させた。)

(3)通風乾燥機のみによる乾燥（通風乾燥機にて $80^{\circ} \mathrm{C}$ 、一昼夜乾燥）

(4)電子レンジによる乾燥（電子レンジにて 2 分 30 秒乾燥）

【結果及び考察】

1)生葉表面を観察すると、半球状の突起が全面に見られた。この突起の直径は約 $10 \sim 20 \mu$ 落での一つ一つが細胞と考えられた（写真 1 ）。

2)生葉亯面には、半球状の突起の他に気孔と毛じが多数見られた（写真 2 ）。

3）断面は、葉表側には柵状組織、葉裹側には海綿状組織と思われる構造が見られ た（写真 3 ）。

4)生葉は観察中、時間の経過とともに乾燥し、表面にてん茶と同様の立体構造が 現れた（写真 4)。

5)古葉の表面は新葉に比べて滑らかで起伏が少なかった。

6)各種乾燥処理葉の断面の厚さは、(1)てん茶炉による乾燥区が最も薄く、次いで (2)蒸熱十通風乾燥区、(3)通風乾燥のみ区、(4)電子レンジ乾燥区であった（図 1)。 7)電子レンジによる乾嬠葉の断面を観察すると、気泡状の細胞間隙が多数見られ た（写真 5 ）。 

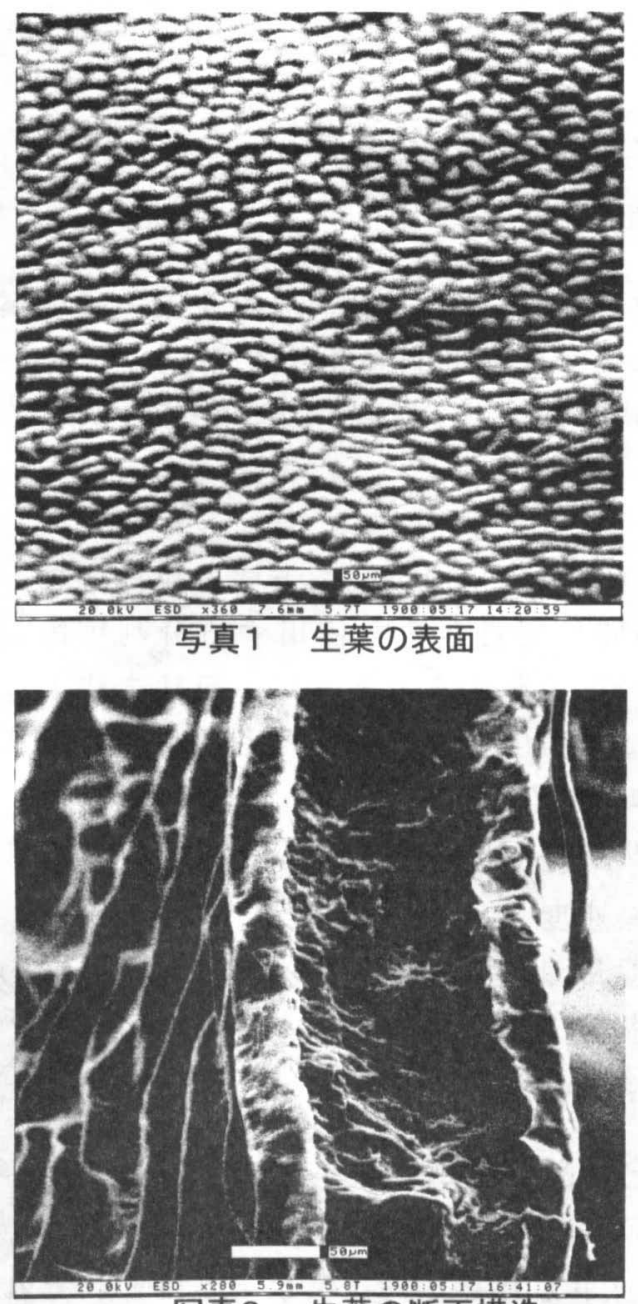

写真3 生葉の断面構造

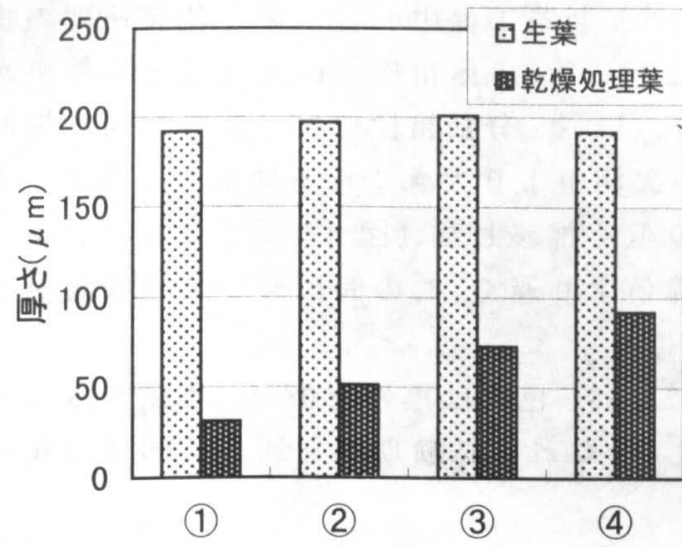

図1各種乾燥処理葉の断面の厚さ (1)て人茶炉による乾燥 (3)通風乾燥のみ (2)蒸熱+通風乾燥勾電子レンジ乾燥
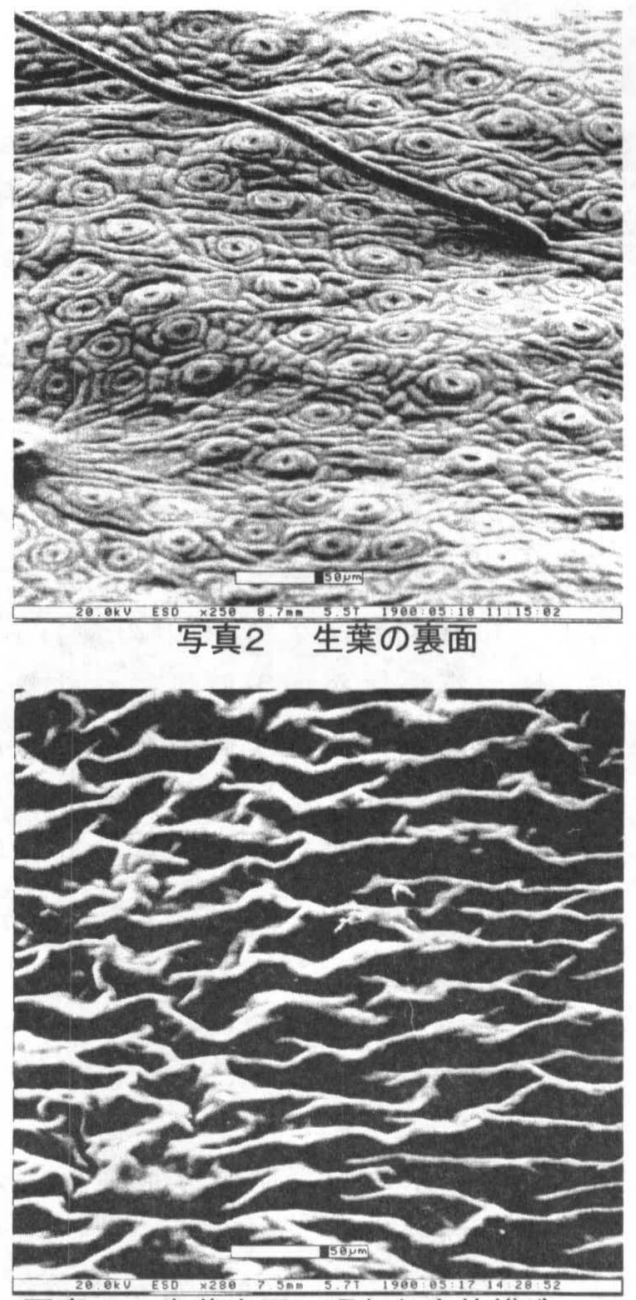

写真4 生葉表面に現れた立体構造

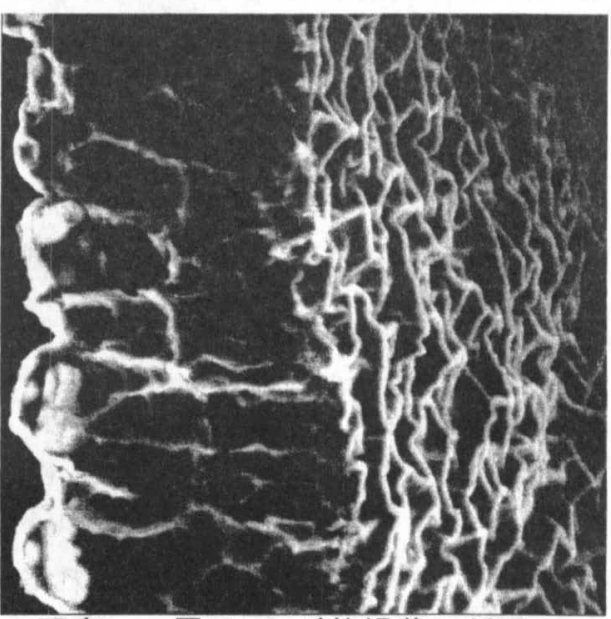

写真5 電子レンジ乾燥葉の断面 
覆い下茶の乾燥特性に適応した粗揉操作

○瀬戸谷隆治・村上宏亮 ·上辻久利 - 牧英樹

(京都府立茶業研究所)

玉露やかぶせ茶では、含水率が高く茶葉が柔らかなこと等、原料生葉の性質が 乾燥経過に及ぼす影響が大きいと考えられるが、その実態は不明な部分も多い。 そこで、粗揉工程における覆い下茶の乾燥特性に適応した操作法ついて、葉打ち 機の利用も考慮し検討した。

【材料及び方法】

供試した材料は一番茶覆い下原料（平成 $9 \sim 11$ 年）で、製茶方法は粗揉機のみ による単体粗揉と、工程中の葉打ち操作期問に葉打ち機を使用する分割粗揉を $35 \mathrm{k}$ 機で行い、覆い下原料における乾燥経過を予測するとともに、粗揉方式の違 いが製茶品質に及ぼす影響を調査した。また工程中の機械操作は各原料や製茶状 況の観察から最も妥当と考えられる方法によった。

工程中含水率及び乾燥速度の計算值は、初期含水率、製茶中の茶温や熟風温度 などから吉富の式

により求めた。 $d m / d t$ : 乾燥速度 $(\% / \mathrm{min})$

$$
d m / d t=-a r^{b}\left(x_{s}-x_{h}\right)
$$

$r$ :質量風量比 (kg dry air/min $\cdot \mathrm{kg}$ dry matter) $x_{s}$ : 茶温に対する飽和絶対湿度 $\left(\mathrm{kg} / \mathrm{kg}^{\prime}\right)$ $x_{h}$ : 給気絶対湿度 $\left(\mathrm{kg} / \mathrm{kg}^{\prime}\right)$

エ程中含水率の実測值は茶葉を 1 分ごとに採取し絶乾法によった。

【結果及び考察】

1）実験結果から $\mathrm{ar}^{\mathrm{b}}$ と質量風量比をプロットしたところ、係数 $\mathrm{a}, \mathrm{b}$ はそれぞれ $0.272 、 1.151$ と推定された（図 1)。

2）得られた倸数 $\mathrm{a}, \mathrm{b}$ を式(1)にあてはめ、製茶工程中の含水率と乾燥速度の推 移について実測值と計算值を比較したところ、単体粗揉では実測值と計算值が、 ほぼ一致した結果となった（図 2、3）。しかし分割粗揉では、葉打ち操作期間 の初期において、乾燥速度の計算值が実測值より大きくなる傾问がみられ、そ れに伴い含水率も計算值が実測值より低く推移した（図 4、5）。これは、葉打 ち操作期間の初期に実際の乾燥が計算值より遅く、この間についての検討がさ らに必要と思われた。

3）製茶品質では分割粗揉が単体粗揉に比べ、色沢は黒みを帯び、香気や滋味で はやや揉み不足で、淡泊な感じを受けた。これは試験期閒を通じて同様の傾向 がみられた（表 1)。

4）覆い下原料で一般に行われる単体粗揉について乾燥速度が推定できたこと から、投入量や吸気乾球温度等の製茶条件を入力し、粗揉操作条件を画面上に 表示するプログラムを作成した（図6）。 


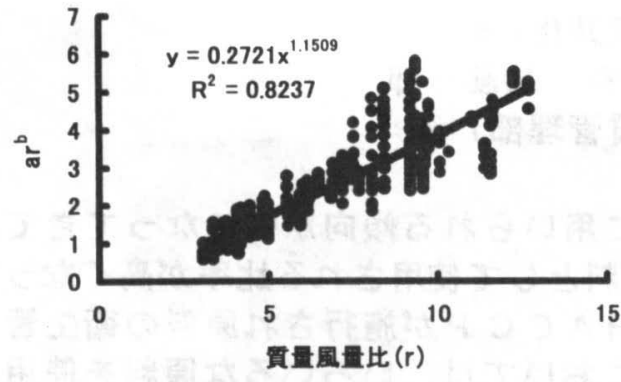

图 1 風量比と係数 $a r^{\mathrm{b}}$ の関係

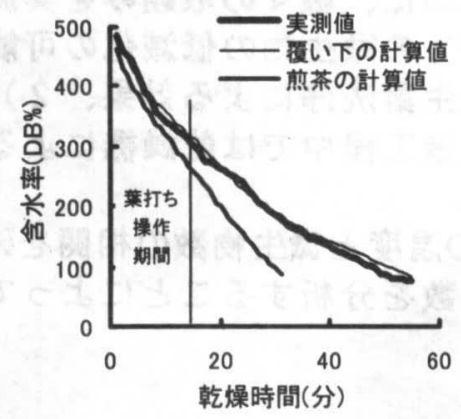

図 2 乾燥時間と工程中含水率(単体粗揉)

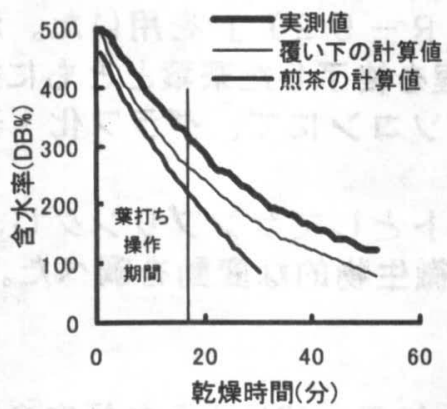

図 4 乾燥時間と工程中含水率(分割粗揉)
表 1 粗揉方法と製茶品質

\begin{tabular}{|c|c|c|c|c|c|c|}
\hline & 形状 & 色沢 & 香気 & 水色 & 滋味 & \\
\hline 割 & 10 & 10 & 18.9 & 10 & 1 & 96 \\
\hline 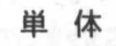 & 19.7 & 19.9 & 19.9 & 19.7 & 19.6 & 98 \\
\hline
\end{tabular}

( 10 反復製茶 2 回審査の平均値)

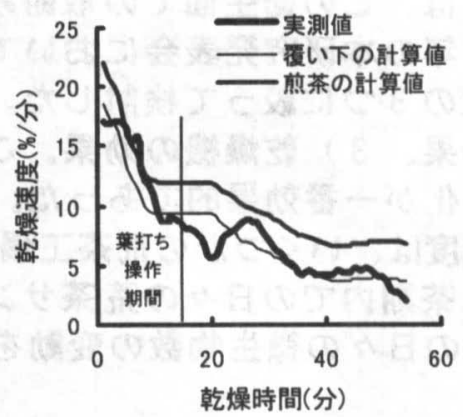

图 3 乾燥時間と乾燥速度 (単体粗揉)

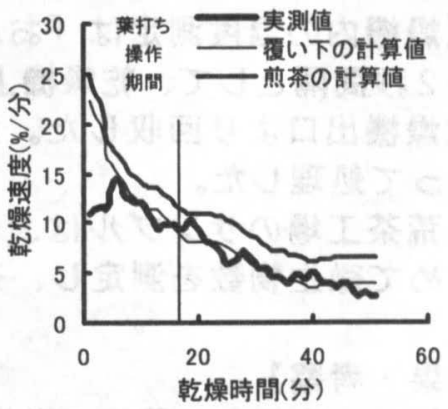

図 5 乾燥時間と乾燥速度 (分割粗揉)

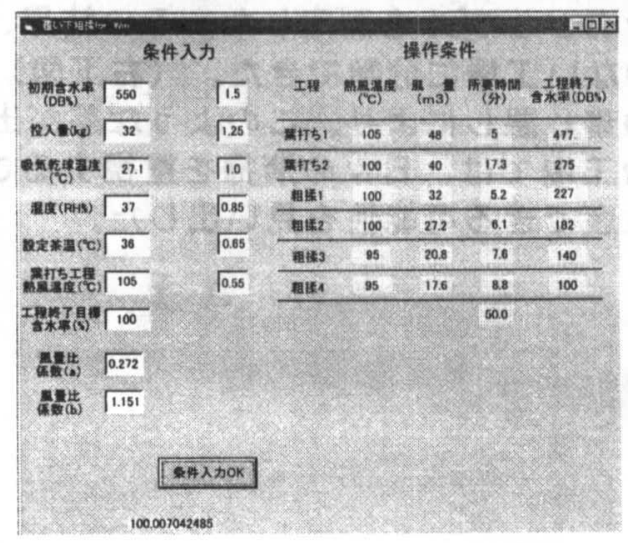

図 6 画面上に示された粗搡操作条件 
荒茶の製造における微生物の低減化-3

沢村信一○・中野恵利・加裂一郎

（株式会社伊藤園 品管理部）

近年、緑杀が本来の飲用の他に種々の用途に用いられる傾向が強くなってきて いる。中でも、今年に入ってから緑茶歕料の原料として使用される比率が高くなっ ている。また、今年度は、清涼飲料においてHACＣＰ加施行され原料の街生管 理の重要性が、再認識されている。㰣料業界においては、いろいろな原料を使用 しているが粶条原料が街生面での取組みが幄れていると再われている。

我々は、この街生面での取粗みを強化するために、盖々の取粗みを実施してき た。昨年の本研究発表会において荒茶製造段陼での检生物の低減化の可能性につ

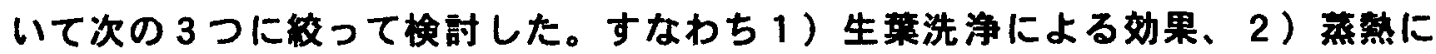

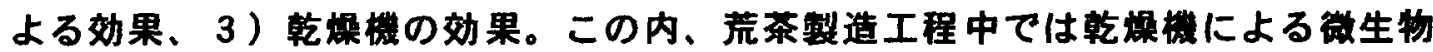
の低㳦化が一番効果的であった。

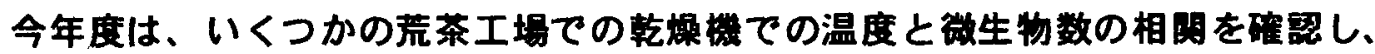
さらに茶期内での日々の荒䒺サンプルの微生物数を分析することによって、各荒 䒺工場の日々の微生物数の变動を調へた。

\section{【诵硂方法】}

1、荒杂の微生物数は食品街生法に基ついて、一般生菌数として求めた。

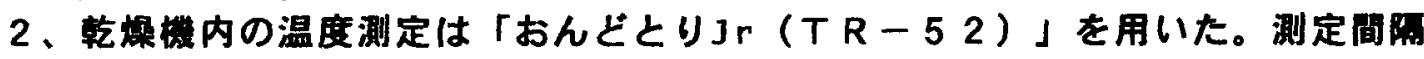

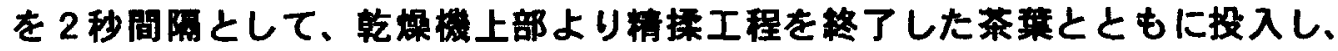
䡎煶機出口より回収した。測定データはパソコンにて、グラフ化・表計算に よって処理した。

3、各荒茶工场のサンプルは、一日分を一ロットとしてサンブリングし、後でま とめて微生物数を测定し、茶期内の工場の的生物的な变髟を調べた。

\section{【結果・考察】}

1、昨年・一昨年度の荒茶の耀生物数を测定した洁果、同しような傾向を示した。 このことは、毎年荒䒺の微生物数がほほ同じ㑯向を持っていることを示唆し ている。また、杂期（一番荼・二番条）間の差も見られなかった。（右上図）

2、各荒茶工場の日々のサンプルを测定した。その結果、徐々に污染の進む工場 とほとんど変化のない工場に分類できた。（右下图）

日々の清堣作業の善し覀しにより、このような差が出たと思われる。 徐↔に污染の進む工埸では、日↔の清搹を重視することにより、より微生物 の少ない荒茶を生産できる可能性を見い出した。 
$98 \sim 99$ 年度産荒茶の微生物数

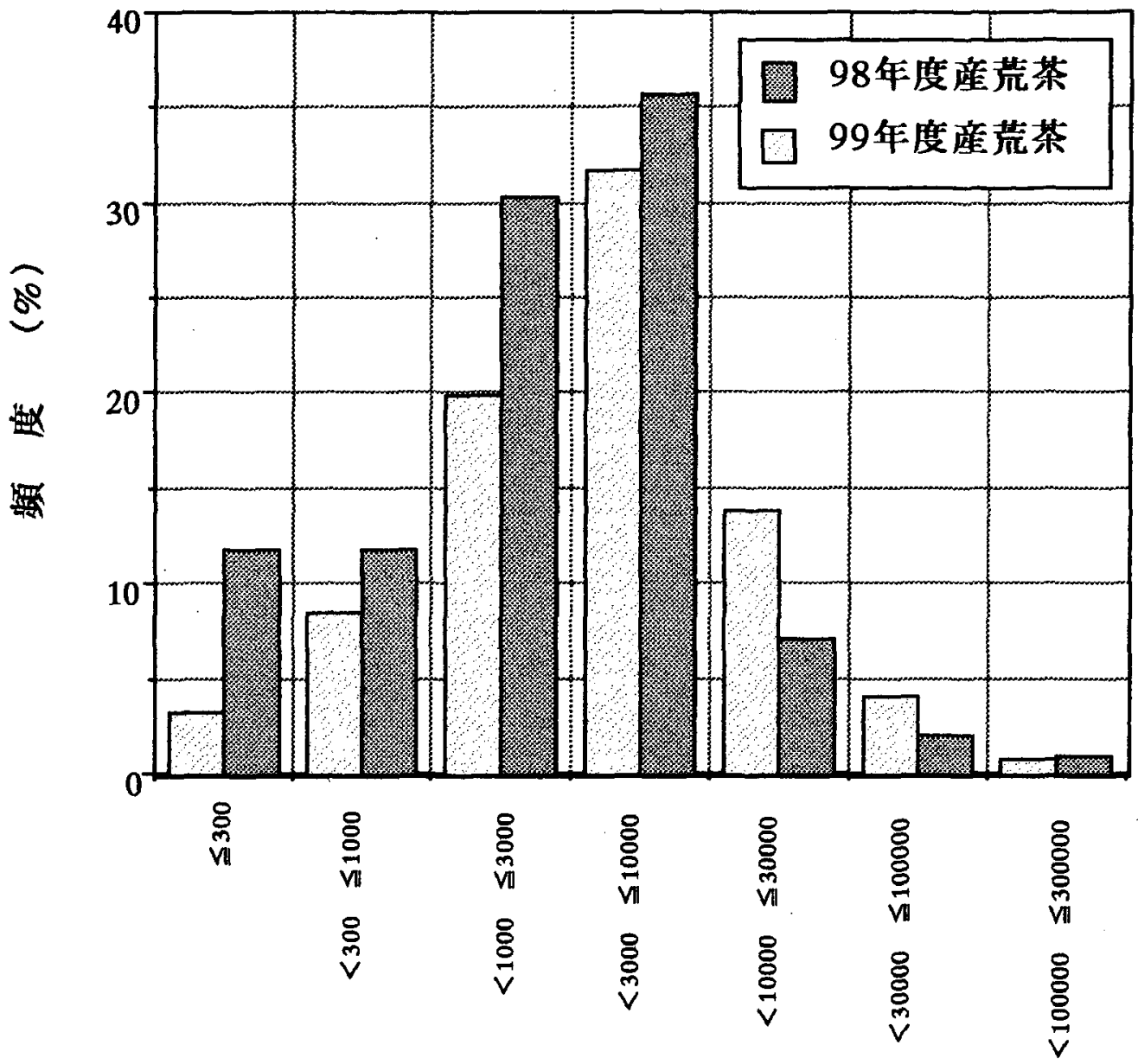

2000 年二番茶時期における各荒茶工場の微生物数の推移

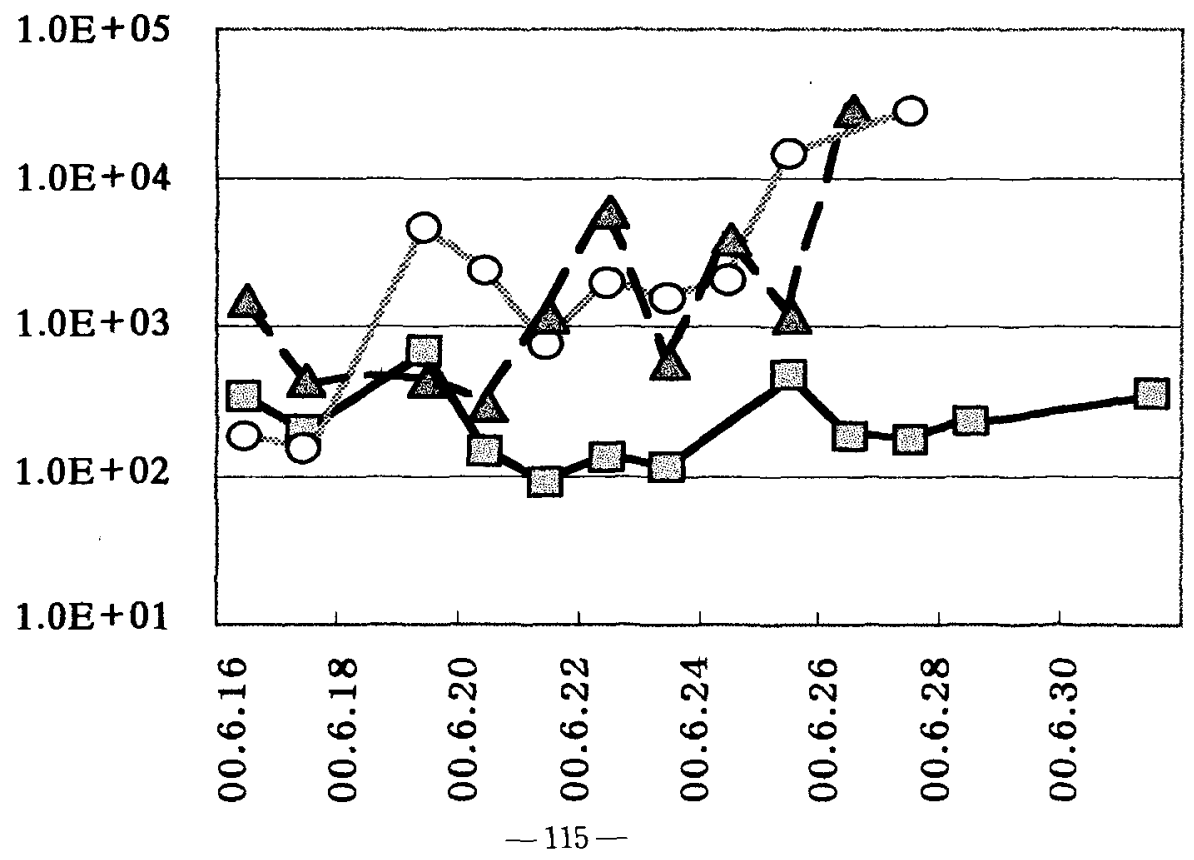


炒り葉の評価に関する研究（第 2 報）

一 葉色による炒りムラの定量化について -

○槐島芳德・永田雅輝・日吉健二

(宮崎大学農学部)

本研究の目的は，釜炒り茶の品質を最も左右する「炒り葉」工程の加工精度を 迅速，かつ定量的に評価するシステムの開発である。第 1 報では，炒りムラの状 態を見出す指標として「葉色」に注目し，減水率と葉色（RGB 值）との関倸につ いて調べた。その結果, 最適減水率時（38４5\%）に抽出色（Blue25-65）が最 大に分布すること（図 3,4 の面積割合 $P$ 参照）がわかった。今回は、炒りムラを 定量的に表す方法として内外比 $S$ を提案し，その解析結果について報告する。

\section{[解析方法]}

茶茟の画像データは，圧縮のない24bitのBitmap 形式で保存される。このフ アイルは, 図 1 に示すフローチャートで作成したVisual C++プログラムで解析さ れる。まず，画像データでは，抽出色が走查され変換色に変更される。ここで， 茶葉の画素数を $A t$, 変換色の画素数を $A c$ とすると, 面積割合 $P$ は以下の式で算 出される。

$$
P=\frac{A c}{A t} \times 100[\%]
$$

一方，内外比 $S$ は，茶葉の外周部と内部画素数とが等しくなるように区分し， 内・外周部における变換色の画素数を $A i$ と $A o$ としたとき,以下の式で表される。

$$
S=\frac{A i-A o}{A i+A o} \quad[-1 \leqq S \leqq 1]
$$

これより，抽出色が内部にのみ分布した時に 1 , 外周部にのみ分布した時にー1 および内・外周部に均等に分布した時に0で表される。炒りムラのない，すなわ ち茶用の内・外周部が均等にかつ適正に加熱される状態を「良好」とすると，今 回の解析では適正な加熱時の葉色が抽出色であるから，内外比 $S$ が 0 に近く，か つ面積割合 $P$ が高いほど良好な加熱が行われたと判断することができる。

以上の内外比 $S$ を求めるためには, 図 2 に示す茶葉画素の外周部と内部に区分 する境界を設定する必要がある。このため，Hilditchの細線化法を応用して境界 線を設定した。この方法は，釜炒り茶のような曲がった形状にも対応できる。

\section{[結果および考察]}

解析の結果を図 3,4 に示す。は面積割合 $P, \triangle$ は内外比 $S$ の算出值, 害線 は面積割合 $P$, 破線は内外比 $S$ の 2 次回帰関数を示す。今回は, 電子レンジ処理 と円筒鉄釜 $200^{\circ} \mathrm{C}$ 処理の内外比 $S$ について考察する。

電子レンジの内外比 $S$ は, 最適诚水率まではほほ平均的に推移し， 1 葉で内側 への分布がやや高い 0.2 程度を示したものの, 最適減水率以降では，著しい内外 比 $S$ の低下が見られた。これより電子レンジでは，内部が優先的に加熱されたと 考えることができる。 
一方, 円筒鉄釜の内外比 $S$ は, 最適减水率前のデータが少なく, 電子レンジ処 理と完全に比較することはできないが, 最適減水率以降もほぼ均等に近い０の值 で変化し， 2 次回帰関数のカーブも緩やかになった。これは, 内・外周部ともほ ぼ均等に加熱されたためと考えられる。この原因は, 茶葉 1 枚のみの処理でムラ の少ない加熱が行われたためと考えられる。

以上から, 炒り葉機の性能の優劣を判断する指標として面積割合 $P$ と内外比 $S$ が有用であることがわかった。今後は, 市販炒り葉機との比較・解析, 面積割合 $P$. 内外比 $S$ と官能審査との関係等について検討する。
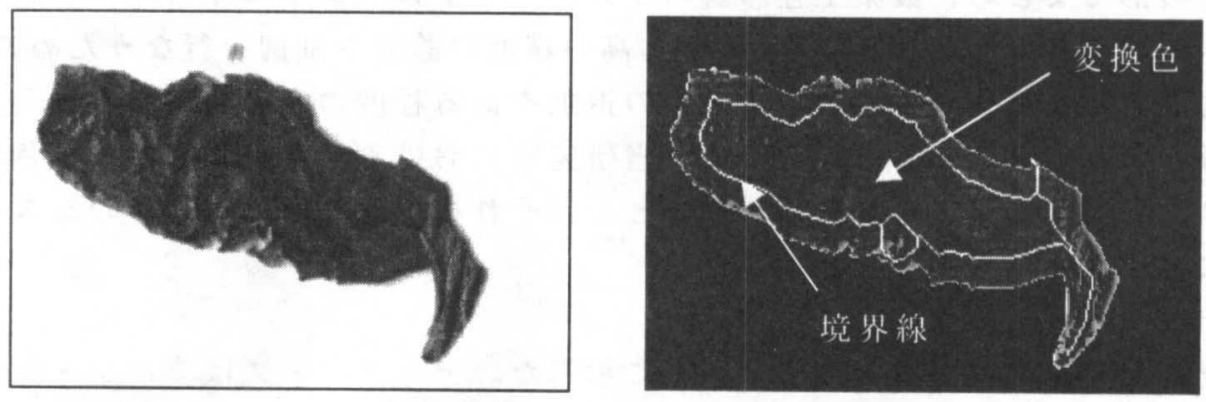

図 2 原画像と解析画像
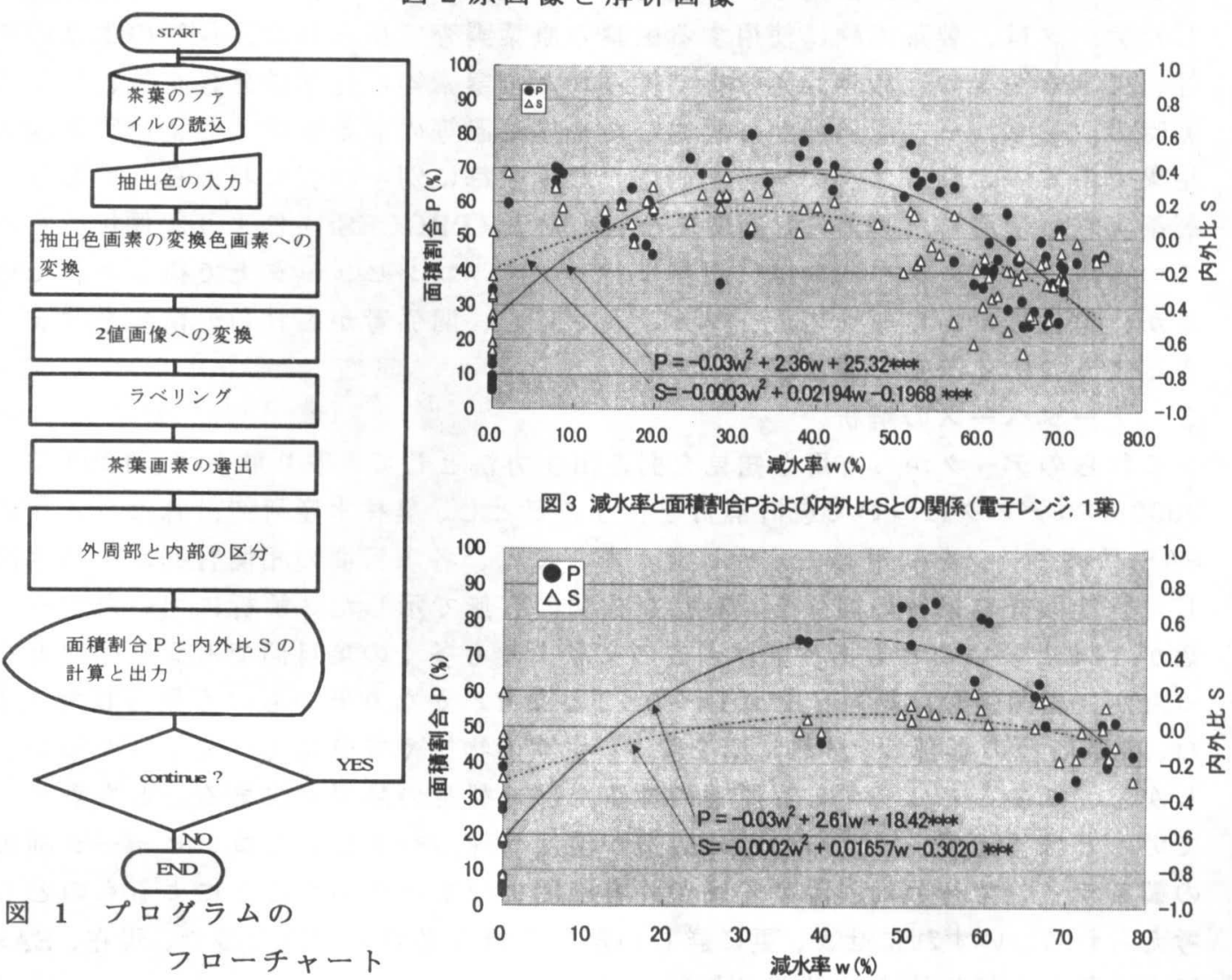

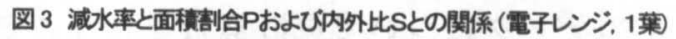

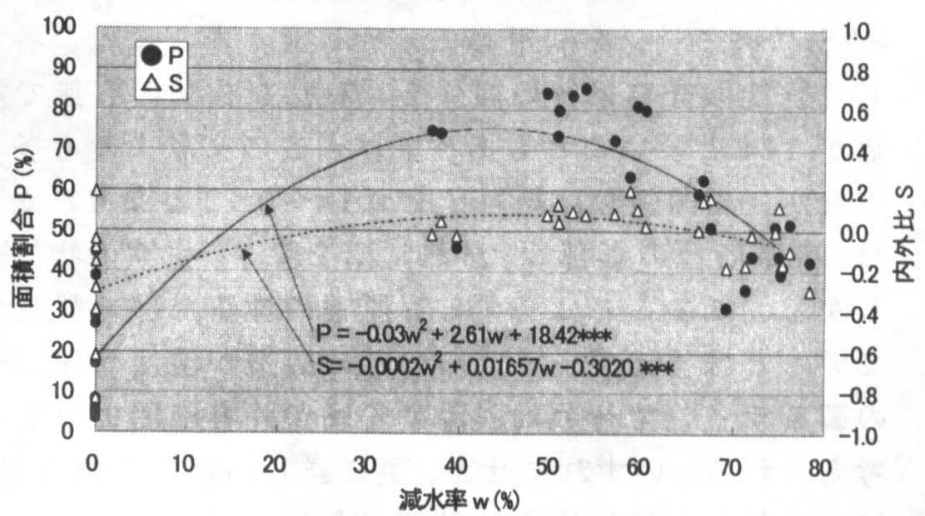

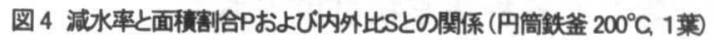




\section{製茶データベースの作成と解析}

吉富 均・山口優一・澤井祐典・深山大介・ ○白尾尚美

（農林水産省野菜・茶業試験場）

\section{1.はじめに}

茶の品質は原葉の性状や製茶条件等によって決まるが、それらの関係は複雑で ある。熟練者達は、経験からそれらの関係をある程度定性的に把握していると考 えられ、高品質茶を作るノウハウとして蓄積してきている。演者らは、これらを ルールの形でまとめ、製茶工程診断エキスパートシステムやエキスパート制御シ ステムに利用しようとしているが、より高い精度の診断や制御を行なうためには、 客観的なデータに基づく新しいルールの追加やある程度の定量的評価の導入が必 要と考えられる。そこで、これまでに当研究室における製茶実験等で蓄積された データを利用し易いデータベースにまとめ、それを解析して、これらのシステム 作成に有用な知見を得ようと試みた。

2. データベースの作成

作成したデータベースの概要を図 1 に示した。データベースは、リレーショナ ルデータベースの手法に則り、正規化された複数の表から構成されている。収録 したデータは、製茶実験に使用する生葉の原葉調查で得られた芽長等の生葉の物 性、できた荒茶の近赤外分光分析で得られた全窒素等の化学成分含有量、製茶実 験時のコンピュータ記録等から要約した平均茶温等の製茶履歴、および官能検査 結果である。これらは、デー夕を取得した実験毎に別々の表に収められており、 製茶実験と使用した原葉の対応関係を収めた表 (PROCESS)により関係付けられ ている。このデータベースは、現在はパーソナルコンピュータ上で構築されてい るが、整備後は、ワークステーション上へ移し、関係者がこれらの情報を共有で きるようにする予定である。

\section{3.データベースの解析}

これらのデータから有用な知見を引き出す方法として、取り敢えず、1998 年〜 2000 年のデータについて統計解析を行うこととし、農林水産研究計算センターの SAS パッケージを利用して分析した。表 1 には、各項目間の相関行列から抜き出 した官能検查結果との関係を、有意な相関の有無で示した。解析に用いたデー夕 数が 114 と多いこともあって、過去の文献よりも多くの頑目間で有意な相関とな ったが、相関係数は絶対值で 0.18〜0.72 となり、かなり低いものも見られた。ま た、製茶履歴の影響は、蒸熱時間を除き、生葉の物性や成分に比べて小さかった。 しかし、このことは必ずしも原葉の性質だけで製茶の品質が決まることを表わし ているとは言えず、これらの茶の製造が温度管理の行き届いたコンピュータ制御 の製茶ラインで行われ、温度履歴が許容範囲に収まっていたことによるものとも 考えられる。いずれにせよ、更に詳しい解析を行う必要を認めたので、現在、SAS による新たな解析法を検討中である。 


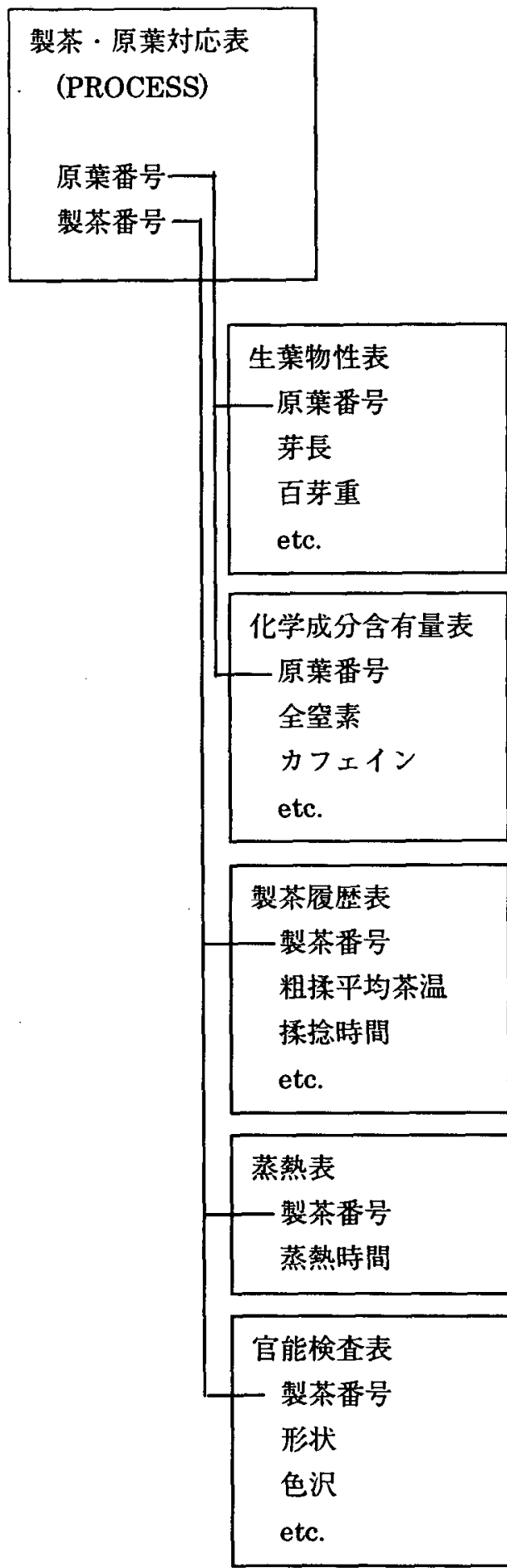

表 1 データ項目間の相関

\begin{tabular}{|c|c|c|c|c|c|}
\hline 項目 & $\begin{array}{l}\text { 形 } \\
\text { 状 }\end{array}$ & $\begin{array}{l}\text { 色 } \\
\text { 沢 }\end{array}$ & $\begin{array}{l}\text { 香 } \\
\text { 気 }\end{array}$ & $\begin{array}{l}\text { 水 } \\
\text { 色 }\end{array}$ & $\begin{array}{l}\text { 滋 } \\
\text { 味 }\end{array}$ \\
\hline 芽長 & $* *$ & ** & $*$ & - & - \\
\hline 百芽重 & $* *$ & ** & $* *$ & - & $*$ \\
\hline 出開き & $* *$ & $* *$ & $* *$ & - & ** \\
\hline 正常茅 & $* *$ & $*$ & $* *$ & - & - \\
\hline 離葉 & ** & ** & $* *$ & - & $* *$ \\
\hline こま切れ葉 & $* *$ & ** & $*$ & - & $*$ \\
\hline 含水率 (全体) & $* *$ & ** & $* *$ & $* *$ & $* *$ \\
\hline 含水率 (葉部) & - & ** & $* *$ & ** & ** \\
\hline 含水率 (茎部) & $*$ & ** & $* *$ & $*$ & ** \\
\hline 葉割合 & $* *$ & $* *$ & ** & - & - \\
\hline 加さ密度 & $* *$ & $* *$ & $*$ & - & - \\
\hline 全窒素 & $* *$ & $* *$ & $* *$ & - & ** \\
\hline カフェイン & $* *$ & *** & $* *$ & - & $*$ \\
\hline タンニン & $* *$ & $* *$ & $*$ & - & - \\
\hline アミノ酸 & $* *$ & $* *$ & $*$ & - & $*$ \\
\hline ビタミン & - & - & - & - & - \\
\hline 轼維 & $* *$ & $* *$ & $* *$ & - & $* *$ \\
\hline テアニン & $* *$ & ** & - & - & - \\
\hline 蒸熱時間 & ** & $* *$ & ** & - & $* *$ \\
\hline 粗揉平均茶温 & $* *$ & ** & - & - & $*$ \\
\hline 揉捻時間 & - & - & - & - & - \\
\hline 中揉平均茶温 & - & - & $*$ & - & - \\
\hline 精揉平均茶温 & - & - & ** & - & - \\
\hline 乾燥平均茶温 & - & * & - & $* *$ & - \\
\hline
\end{tabular}

注）**：1\%の危険率で相関あり

*： $5 \%$ の危険率で相関あり

一： 相関なし

図1データベースの構成 


\section{オンライン生葉評価システムのための計測手法の検即}

深山大介 - 中山 循*. ○野口公輝 - 吉冨 均 - 山口優一 ・澤井祐典

（野菜・茶業試験場， *株式会社寺田製作所）

現在，製茶施設における荷受け生葉の評価は熟練者による官能評価に頼ってい るため, 客観的な評価手法が求められている. 特に大規模製茶施設では品質向上に つながる合葉の判断基準としてオンラインで荷受け生葉の評価が可能となるシステ ムが求められている. 最近では近赤外分光分析器を利用して化学成分を求める手法 が普及しているが，その手間や全量計測でない点など実用面では問題が多い。そこ で, 本報告では，製茶施設の生葉受け入れラインに組み込まれ，非接触・非破壊で かつオンラインで全量計測が可能となる生葉評価システムの開発を目的として, 特 に生葉の化学成分を計測するためのシステムを試作し検討した.

【材料及び方法】

オンライン生葉評価システムの概念を図1に示す．現段階では想定している評価基 準は合葉のための格付けを主たる目的とするものであり, 評価項目として生葉含水 率や総䋐維，全窒素に着目した．試作したオンライン生葉評価用成分計の概略を図 2 に示す．試作成分計はコンベア上を流れる供試生葉表面の反射光をバンドパスフィ ルタにより4波長帯に分光し, 算出した各波長帯の吸光度による回帰式を検量線とし ている．供試した生葉は一番茶および二番茶全期間に菊翠茶農協（金谷町）に持ち 込まれた生葉を用いた. サンプルの一部は乾燥・粉砕処理の後, 近赤茶成分計によ り窒素・総織維をあらかじめ測定した．また，二番茶のサンプルの一部は全空素分 析装置で窒素含量を求め, これらの化学成分值と試作成分計による推定値を比較検 討した.

【結果及び考察】

試作成分計による全窒素含量の計測結果を図3に示した．一番茶期で相関係数 $\mathrm{r}=0.793$, 二番茶期では茶期後期のサンプルで誤差が生じているが概ね良好な線形関 係が認められた. 用いた検量線は共に一番茶生葉で作成したものであるが, 今後, 茶期ごとの検量線の必要性やその年次変動について検討する必要があった.

図4には試作成分計による総䋞維の計測結果を示した．高い相関関係を示している が，試作成分計による計測結果の比較対象が近赤茶成分計によるものであり，とも に近赤外光を用いた手法であることから注意が必要であるが, 比較的高い精度での 非接触・非破壊計測の可能性を示したものと考えられた. 試作成分計による生葉含 水率の計測は図5に示すように比較的高い精度での計測が可能であったが, 茶葉の状 態によっては推定精度が低下する場合があり, 今後詳しく解析する.

以上のことから，合葉のための生葉評価を目的とし，化学成分を非接触非破壊計 測するシステムは, 茶期ごとの検量線や安定した含水率計測法の確立等の問題はあ るが実現の可能性は示されたと考えた. 今後は, 生葉形状や物理性など化学成分以 外の計測法の確立を進める必要がある. 


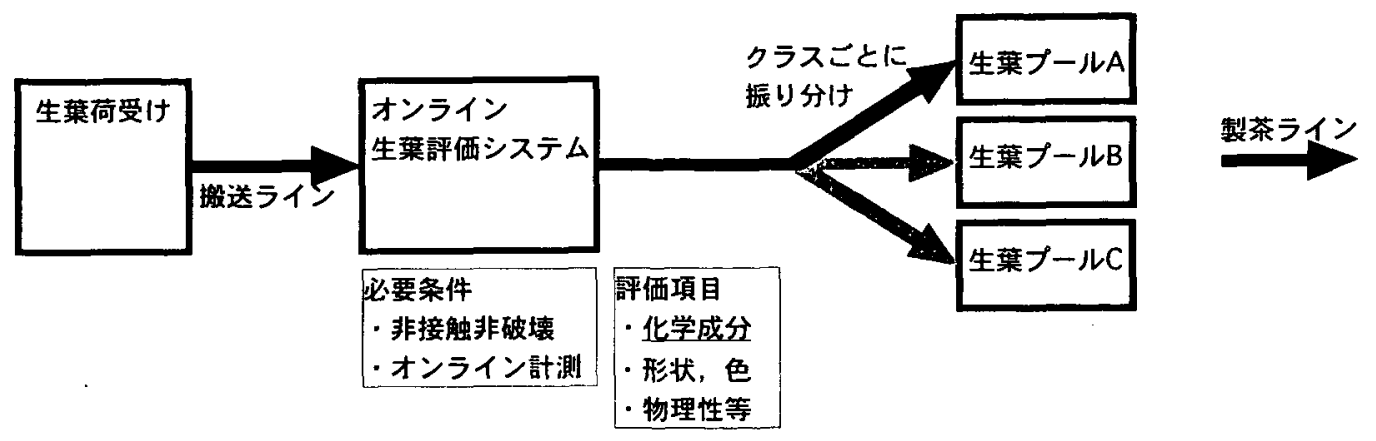

図1 オンライン生葉評価システムの概念

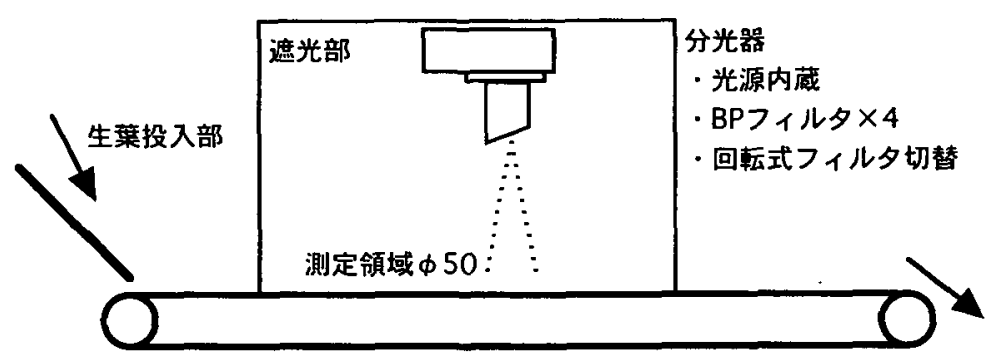

図2 オンライン生葉評価システム試作成分計
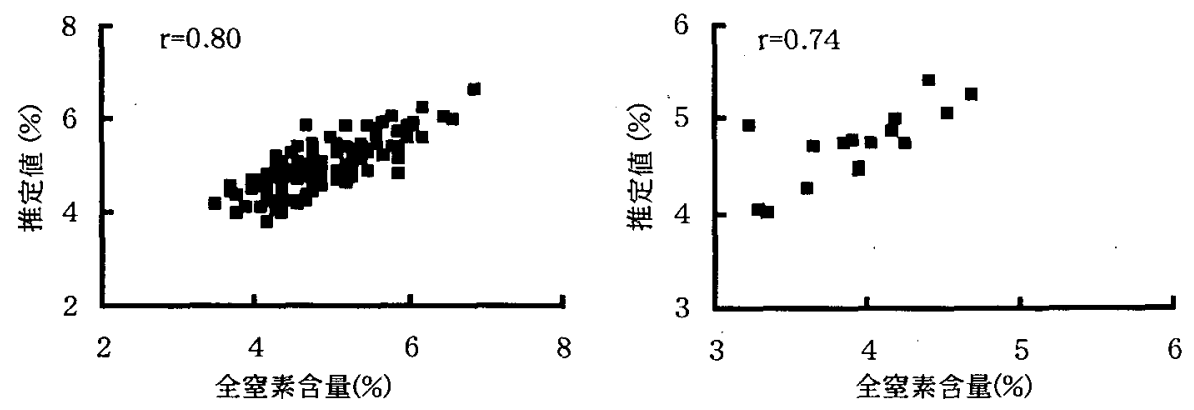

（a）一番茶．全空素含量は近赤茶成分計による

(b) 2 番茶. 全空素含量は全空素分析装置による 図3試作成分計による生葉全等素含量の計測結果
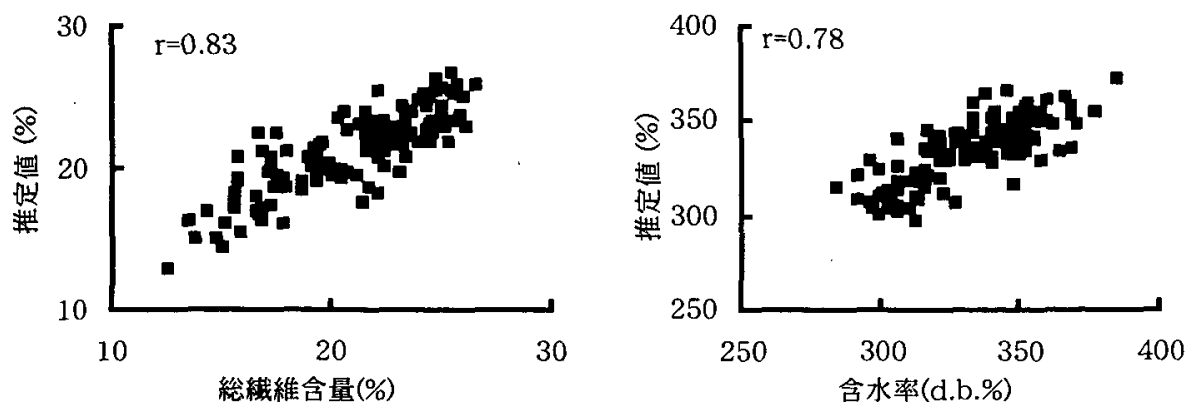

図4 試作成分計による総辂維含豆の計測結果 図5 含水率の計測結果（一番茶）

(一番茶、総緉維含量は近赤茶成分計による) 


\section{荒茶色沢の評価技術の開発 \\ ○入来浩幸・樋口雅彦・佐藤昭一・吉田高晃 \\ （鹿児島県茶業試験場）}

荒茶品質評価項目のなかで，色沢の評価は品質を左右する重要な項目である。 しかしながら，現在ではその微妙な差を特定するためには熟練された審查員の官 能評価によるところが大きい。また，測色色差計を用いて色の数值化が簡単にで きることが報告されているが，現場での普及性としては十分でない。

そこで，近年進歩の著しい画像処理技術を用いて，荒茶色沢をより迅速に簡易 に評価する技術の開発を試みた。

\section{【試験方法】}

荒茶表面の色度は，測色色差計：ZE-2000（日本電色工業株式会社製）で荒茶节 ンプル用の大型丸セル $\phi 48$ 用いて測色した。

荒茶の表面画像取得には，TRUE-LITE蛍光灯を備え，211万画素のデジタルカメ ラ：C-2020Z00M（OLYMPUS社製）を取り付けた色調機（カワサキ機工株式会社製） を用いた。画像取得条件は，カメラ絞り：3.2,シャッター速度：1/50 secで撮影 L，その後取得した画像のR G B 值から $\mathrm{L} * \mathrm{a} * \mathrm{~b} *$ 表色系への変換を行った。さらに 測色色差計から求めた $L * a * b *$ 值とデジタル画像から変換した $L * a * b *$ 值との比較を 行った。

また，色沢審查概評の表色系での数值化を図るため，デジタル画像の R G B 值 により判別分析を行い色沢審查概評の画像への適用性を検討した。

\section{【結果及び考察】}

（1）一番茶における審查概評を，L*a*b*表色系の L*a*b*を用いた判別分析で，色沢 の黒みのものと赤みの傾向のものに判別できた。また黒みのものは，さらに，濃 緑，標準，良好，の群と鮮緑，色あさし，さえ不足，つや不足，ささ色の群に高 い精度で判別できた（図 1 ）。

(2)測色色差計で測色した荒茶の色度とデジタルカメラから得られた色度には, 高 い相関（L值：r=0.816**，a*值：r=0.791**，b*值：r=0.891**）が認められた。

また, デジタル画像から得られる值は, 測色色差計に比べ色度の分布幅が人の 感覚と一致し，デジタル画像を荒茶色沢の評価に活用できることが示唆された

(図 2,3)。

（3）荒茶色沢の審査概評の適用を量的に行うため，図 5 の評価手順で行った。教師 サンプルの選択と人による判断との精度を高めて分析することにより，デジタル 画像から荒茶色沢評価ができると考えられた（図 5，表 1)。

以上の結果から，荒茶色沢の評価が量的に，しかも簡易にできることが明らか になった。今後サンプル数を増やして精度を高めることにより，荒茶色沢評価の 量的定義付けができると考えられた。 


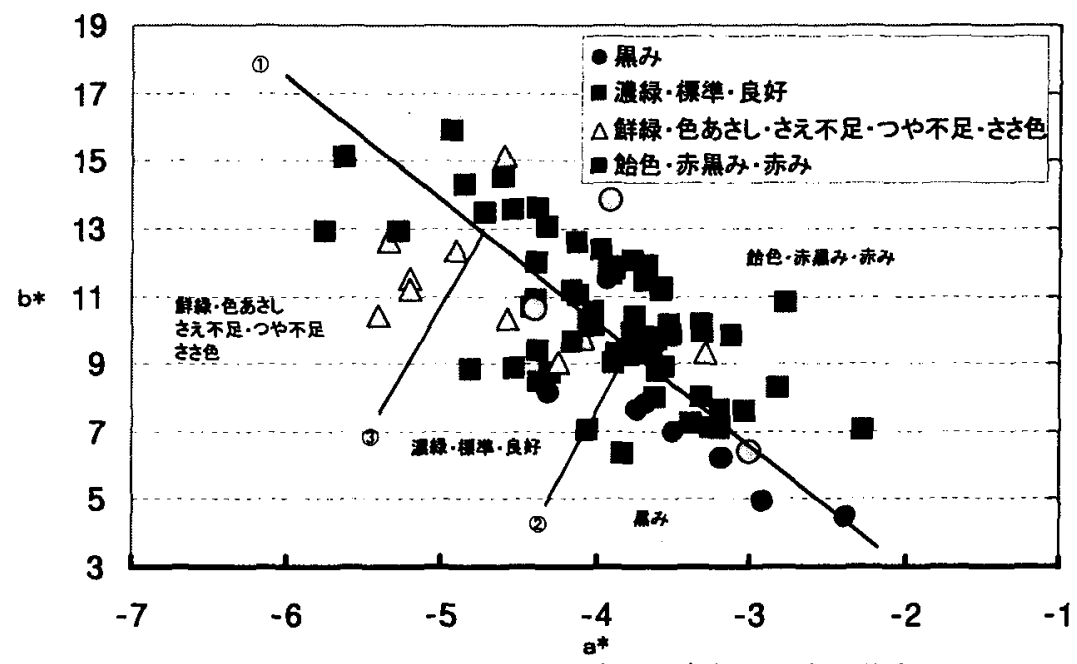

鹿児島県茶市場 1999年上場茶 137 点（左図） (1), (2), (3) は判別 式による境界

图 1 茶市場一番茶上場茶の色度( $a *, b *) の$ 分布
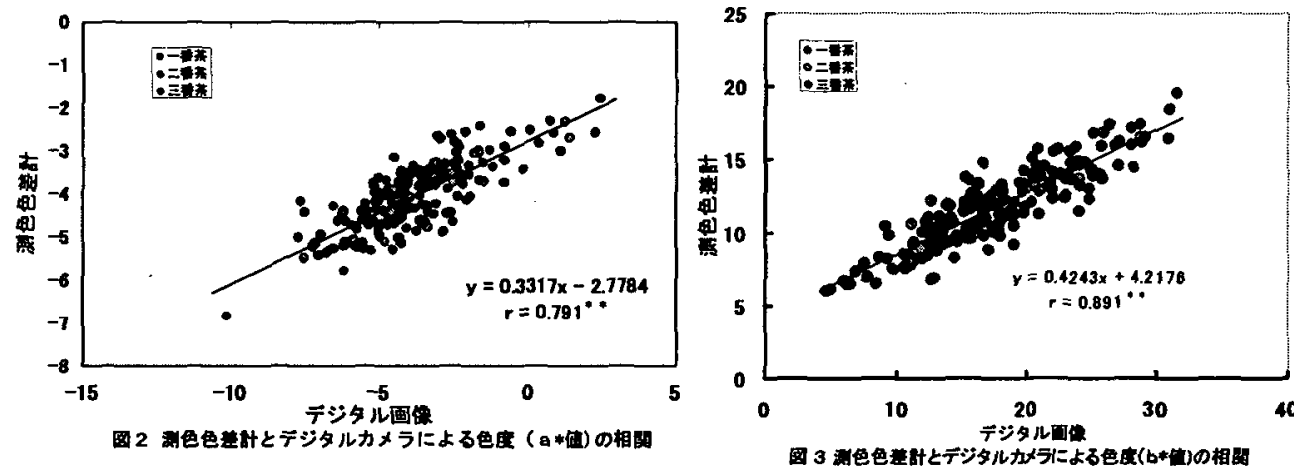

表 1 教師色の画素值から得られた判別式と判別式による代表的画像の画素数

\begin{tabular}{|c|c|c|c|c|c|c|c|}
\hline 教師色 & $\mathrm{R}$ の係数 & Gの係数 & B の係数 & 定数 & 黒み & 赤み & 濃緑 \\
\hline 飴 色 系 & 0.267 & 0.113 & -0.206 & -12.496 & 708 & 20609 & 864 \\
\hline 黒色 系 & 0.023 & 0.216 & -0.089 & -6.240 & 102026 & 27450 & 51828 \\
\hline 笹 色 系 & -0.116 & 0.735 & -0.270 & -35.958 & 8441 & 21918 & 14238 \\
\hline 赤 み系 & 0.141 & 0.187 & -0.157 & -9.798 & 1025 & 22222 & 2699 \\
\hline 赤黒み系 & 0.111 & 0.202 & -0.142 & -9.276 & 6304 & 17475 & 11163 \\
\hline 濃 緑 系 & -0.268 & 0.676 & -0.187 & -15.748 & 39190 & 44329 & 78393 \\
\hline 白 茥 系 & -0.131 & 0.837 & -0.259 & -54.681 & 2911 & 4536 & 1504 \\
\hline 木䒚系 & 0.751 & -0.162 & -0.308 & -38.678 & 196 & 2262 & 112 \\
\hline
\end{tabular}

\begin{tabular}{|c|c|c|c|c|c|}
\hline 画像取得 & $\rightarrow$ & $\begin{array}{l}\text { R G B 值による } \\
\text { 判別分析 }\end{array}$ & $\begin{array}{l}\text { 判別された画素 } \\
\text { 数の割合評価 }\end{array}$ & $\longrightarrow$ & $\begin{array}{l}\text { 色沢の絶対評価 } \\
\text { 概評の指摘 }\end{array}$ \\
\hline
\end{tabular}

図 4 色沢の評価手順 


\section{葉緑素の変成に及ぼす含水率・温度・時間の影響（第 2 報） \\ 精琭・乾燥工程での葉緑素の変化 \\ ○樋口 雅彦・入来 浩幸・佐藤 昭一・吉田 高晃}

（鹿児島具茶業試験場）

演者らは葉緑素の変成要因を明らかにするためのモデル試験を実施し，製茶工 程中での色素変化量は, 含水率・温度・時間により体系的に説明できる可能性が あることを報告した。そこで本報では，実際に精揉，乾燥工程での葉緑素の変成 をこれらの要因で体系的に説明するための試験を実施した。

\section{【試酸方法】}

試験には一番茶やぶきた露地原料を用い，60 K 型製茶機械で中拯または精㧫 まで製造したものを供試した。精揉はカワサキ式精揉機に 1 揉み釜当たり $4.2 \mathrm{~kg}$ ， 乾燥は寺田式棚式透気乾燥機に 1 段当たり $4.0 \mathrm{~kg}$ を投入し供した。精揉工程は火 室温度を $90{ }^{\circ} \mathrm{C} \cdot 100^{\circ} \mathrm{C} \cdot 110^{\circ} \mathrm{C}$ の 3 水準とし, 15 分毎にサンプリングし冷凍保存 し, 乾燥工程は熱風温度を $60^{\circ} \mathrm{C} \cdot 75^{\circ} \mathrm{C} \cdot 90^{\circ} \mathrm{C}$ 水水とし, 10 分毎にサンプリ ングし, 40 分で取り出し窒素封入後冷藏保存し分析試料とした。試料の調整法 及び色素類含有量測定法は, HPLC 法によるクロロフィル関連色素類同時分析法 に基づき行った。

\section{【結果及び考察】}

1) Chl 含量及び Chl 総量"'は，精捼工程においては時間の経過に伴い減少する

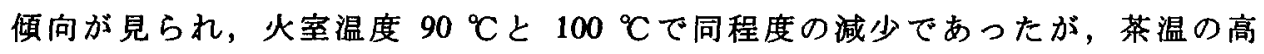

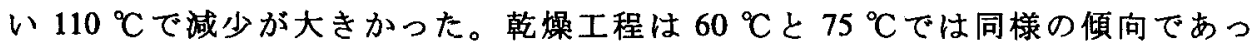

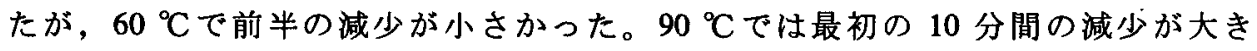
く, その後は小さな変化であった。また, Phy 含量は精採・乾燥工程ともに增 加が小さいため, 結果として Chl 総量は減少した。Chl の Phy への変化率は Chl 含量の減少に伴い大きくなった。工程間の比較では含水率の少ない乾燥の方が 色素類の変化量は小さかった（図1，2）。

2）既存の報告より製茶工程が進むに従って，Chl の減少及び Phy の増加が知ら れているが，精揉・乾燥での低含水率域では Phy 含量とChl の Phy への変化率 の相関係数は $\mathrm{r}=0.5766$ と低く, Chl 含量と変化率の関係は $\mathrm{r}=0.9835$ と高かった。

これは, 精採工程以降の低含水率域では Chl の Phy への変化だけではなく, Chl そのものの減少やChl が Phyに変化した後, Phy が減少するなどの変化が起 きていると推察された（図 $1 \sim 4$ )。

3) 各サンプルでの Chl 総量に対する Chl の割合を Chl 残存率とし, 目的変数を $\mathrm{Chl}$ 残存率 $(\mathrm{Y})$, 説明変数を含水率 $\mathrm{X}_{1}$, 茶温 $\mathrm{X}_{2}$, 時間 $\mathrm{X}_{3}$ とすると重回帰 式 $\mathrm{Y}=0.097 \mathrm{X}_{1}-0.054 \mathrm{X}_{2}-0.072 \mathrm{X}_{3}+75.877 \quad\left(\mathrm{R}^{2}=0.8166\right)$ が得られ, 経過時間が 短く含水率の高いかつ茶温の低い条件下でChl の残存率は高かった（図 5 . 表 1 )。

以上のことより, 比較的低含水率域では Chl の Phy への変化率より, Chl 含量 が色沢判断に適すると考えられる。

1) Chl 総量はPhya,PhybをChla,Chlbに換算し合計した。 

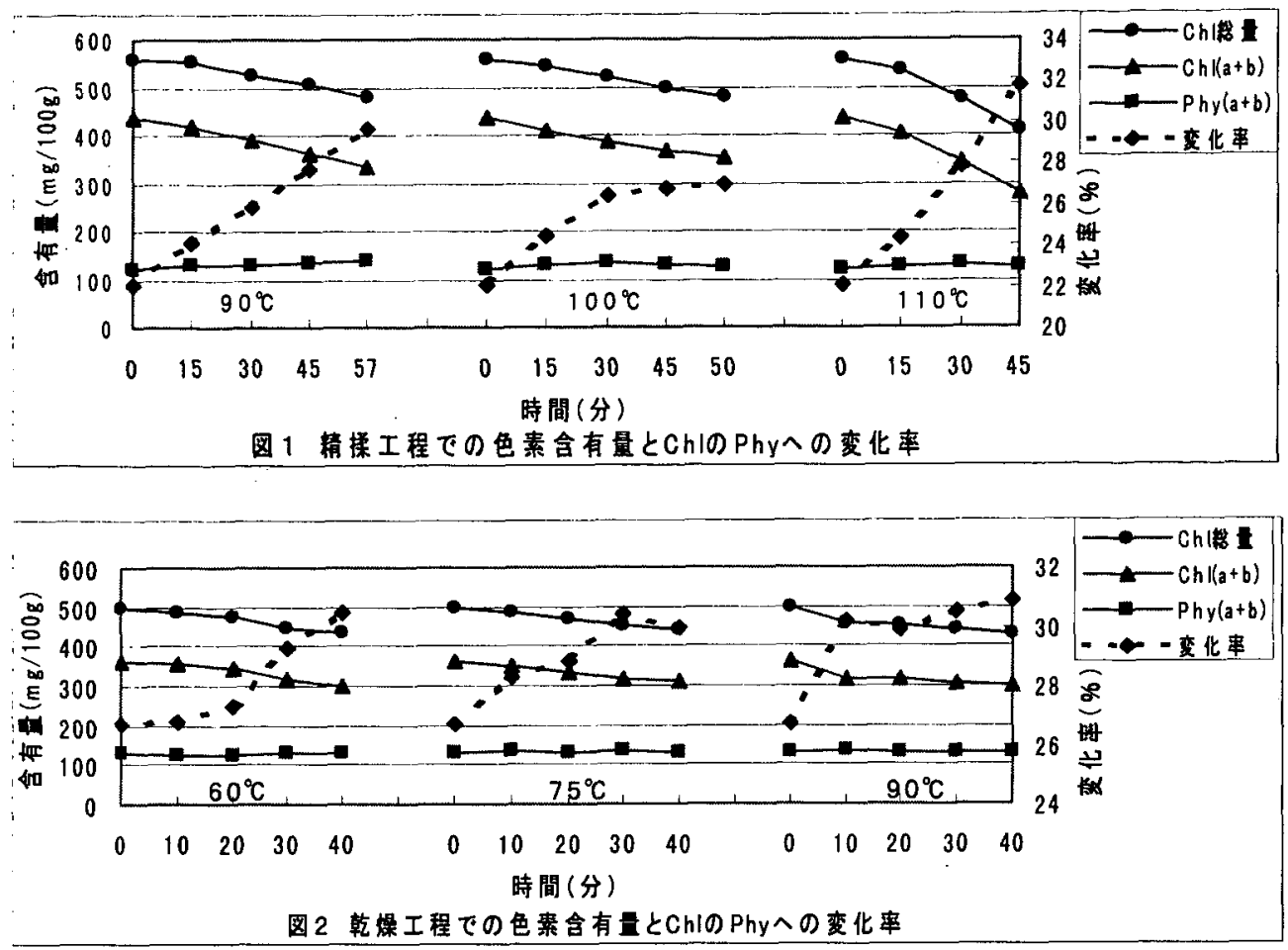

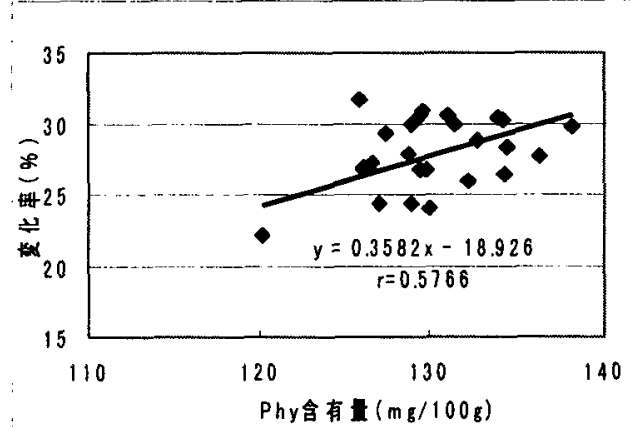

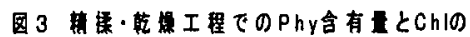
Phyへの变化事

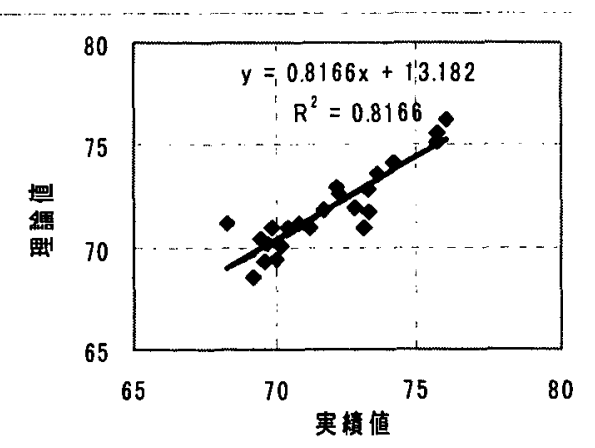

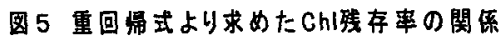

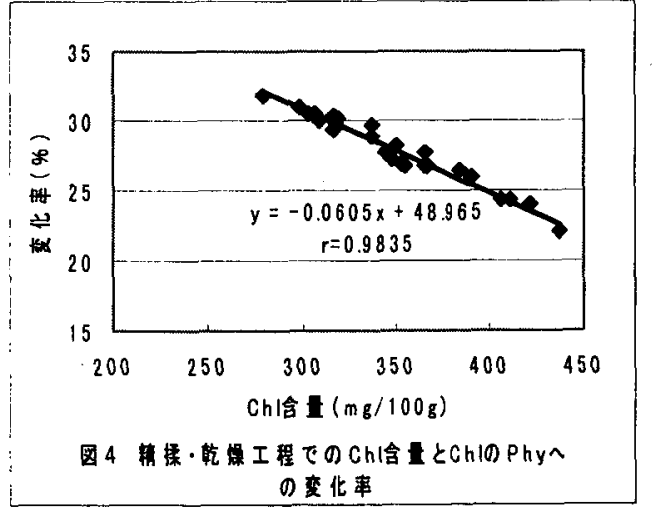

表 1 重回㷌式による Chl 残存率の推定

\begin{tabular}{|c|c|c|}
\hline 説明変数 & 偏回绵係数 & 標準疤回襢係数 \\
\hline 含水率 & 0.097 & 0.424 \\
\hline 茶 温 & -0.054 & -0.435 \\
\hline 時 間 & -0.072 & -0.444 \\
\hline 定数項 & 75.877 & \\
\hline
\end{tabular}

